\title{
Insights into extensional processes during magma assisted rifting: Evidence from aligned scoria cones
}

\author{
Tyrone O. Rooney ${ }^{\mathrm{a}, *}$, Ian D. Bastow ${ }^{\mathrm{b}}$, Derek Keir ${ }^{\mathrm{c}}$ \\ a Deptartment of Geological Sciences, Michigan State University, East Lansing, MI 48824, USA \\ b Department of Earth Sciences, University of Bristol, Bristol, BS8 1RJ, UK \\ c School of Earth and Environment, University of Leeds, Leeds, LS2 9JT, UK
}

\section{A R T I C L E I N F O}

\section{Article history:}

Received 28 March 2010

Accepted 18 July 2010

Available online 25 July 2010

\section{Keywords:}

East African Rift

Ethiopia

volcanism

extension

geochemistry

rifted margin

\begin{abstract}
A B S T R A C T
Mechanical and magmatic processes exert first-order control on the architecture and evolution of rifts. As a continental rift develops towards a new oceanic spreading centre, extension that is initially accommodated in a broad zone of faulting and ductile stretching must transition towards a narrow zone of focused magmatic intrusion. The Main Ethiopian Rift (MER), part of the East African Rift System, is an ideal location to study this transition because it captures rifting processes during continental breakup. In this contribution we synthesise geochemical data from scoria cones in the Wonji Fault Belt (WFB) and Silti-Debre Zeyit Fault Zone (SDFZ) in the MER to provide new constraints on the development of mantle melting columns and magmatic plumbing systems since the onset of rifting. We utilize the extensive geophysical and geochemical databases, collected in the Ethiopian Rift, to show that geochemical evidence of heterogeneity in the depth of the mantle melting column which produced Quaternary rift basalts correlates with lithospheric structure. When combined with existing observations of asymmetry across the rift in terms of depth of melting column and magmatic plumbing systems, it is evident that the mechanical structure of the rift, defined during the initial stages of breakup, has played a dominant role in the initial development of magma assisted rifting in the MER. Surface structures and crustal-scale geophysical studies have suggested the WFB is analogous to a sea-floor spreading centre. However, the geochemical characteristics of rift basalts are consistent with mantle tomography that shows no evidence beneath the MER for passive magmatic upwelling beneath discrete rift segments as is observed in the ocean basins. Collectively, the Ethiopian data show that the distribution of mantle melts during the initiation of magma assisted rifting is fundamentally influenced by lithospheric structures formed during earlier syn-rift stretching.
\end{abstract}

(c) 2010 Elsevier B.V. All rights reserved.

\section{Introduction}

Continental rifts are initially characterised by relatively broad zones of 'mechanical' extension in which faulting and stretching of the lithosphere accommodates strain. Ultimately, however, the locus of extension must shift towards narrow zones of magma intrusion at a new oceanic spreading centre. Recent studies of continental rifts (e.g., Ethiopia: Mackenzie et al., 2005; Baikal: Thybo and Nielsen, 2009), and passive margins (White et al., 2008) show increasingly that extension of the continental lithosphere is accommodated in part by the intrusion of magma into the plate prior to rupture, without marked crustal thinning. Such observations have important implications for the estimation of stretching factors and thus the thermal evolution of potentially hydrocarbon-rich passive margins worldwide. Despite the obvious need to incorporate magma intrusion, however, traditional kinematic (e.g. McKenzie, 1978) and more recent

\footnotetext{
* Corresponding author. Fax: + 15173538787.

E-mail address: rooneyt@msu.edu (T.O. Rooney).
}

dynamic (e.g. Huismans and Beaumont, 2003) rifting models have regarded melt only as a by-product (e.g., continental flood basalts) of extension, and not a mechanism by which it is achieved.

Ethiopia provides a unique opportunity to understand the role of magma intrusion during continental breakup because it exposes subaerially several stages of rift evolution from juvenile continental rifting in the south, to incipient sea-floor spreading in Afar (e.g. Ebinger and Hayward, 1996; Hayward and Ebinger, 1996; Ebinger and Casey, 2001). Recent international collaborative experiments, in particular the Ethiopia Afar Geoscientific Lithosphere Experiment (EAGLE: e.g. Bastow et al., in press and references therein), have probed this region using a suite of geophysical and geochemical tools including passive and controlled source seismology, magnetotellurics, gravity surveying, and isotope geochemistry to place new constraints on present day extension in Ethiopia. The south-to-north exposure of progressively evolved stages of rifting means that these results can be used to understand the evolution of rifting processes over time, and in particular the changing role of magma intrusion in accommodating extension.

Structural and crustal-scale geophysical studies of the MER cite evidence of discrete zones of magmatic intrusion in the crust to 
suggest that the early stages of mid-ocean ridge development are already underway (e.g., Ebinger and Casey, 2001; Keranen et al., 2004; Casey et al., 2006). In contrast, the velocity structure of the uppermost mantle shows no correlation with crustal magmatic segmentation, with the implication that processes in the ocean basins are not yet operating beneath the MER (Bastow et al., 2005, 2008). The geochemical properties of rift magmatism can reveal details of the magmatic plumbing system, degree of lithospheric thinning, and changes in properties or proportions of the magmatic reservoirs that contribute to rift volcanism. A coupled geochronological and geochemical study of rift magmatism therefore provides a fresh opportunity to place constraints on the spatial and temporal development of rifting during the transition from continental rifting to sea-floor spreading.

In continental rifts, a significant proportion of magma intrudes continental lithosphere in the form of near vertical dikes (e.g. Parsons and Thompson, 1991; Kendall et al., 2005; Rooney et al., 2005; Behn et al., 2006; Buck et al., 2006; Wright et al., 2006; Calais et al., 2008; Keir et al., 2009b; Bastow et al., 2010). These intruded dikes may induce faulting in the brittle upper crust (e.g. Rubin and Pollard, 1988; Rubin, 1990; Keir et al., 2006a; Wright et al., 2006; Ayele et al., 2009; Hamling et al., 2009), or where the dike intersects the surface, aligned chains of scoria cones and fissural flows form during volcanic eruption (e.g. Nairn and Cole, 1981; Cole, 1990; Chadwick and Dieterich, 1995; Ferguson et al., 2010). In this contribution we track the evolution of continental breakup by focusing on the magmatic products of cinder cones located in the MER. Significant developments in understanding the geochemical reservoirs which contribute to rift magmatism (e.g. Hart et al., 1989; Deniel et al., 1994; George and Rogers, 1999; Furman et al., 2006) have focused attention on the relationship between rift magmatism and extensional processes within the MER (Rooney et al., 2007; Rooney, 2010). This study utilizes existing geochemical and geophysical data and interprets them in the context of recent geodynamic models (e.g. Ebinger and Casey, 2001; Buck, 2006; Bialas et al., 2010) to place new constraints on the nature of the transition from broad mechanical extension (faulting and stretching) towards narrow zones of magma intrusion prior to the onset of sea-floor spreading.

\section{Continental rifting in East Africa}

\subsection{Structural and temporal constraints on rifting in the MER}

The role of melt emplacement in facilitating continental rupture has been highlighted as geodynamic studies have shown that the tectonic force needed to initiate and maintain breakup of thick continental lithosphere in the absence of melt is greater than that typically available (Kusznir and Park, 1987; Hopper and Buck, 1993; Buck, 2004; Buck, 2006; Bialas et al., 2010). Ultimately, however, the locus of extension in rifts that develop to the point of rupture shifts towards narrow zones of magma intrusion as a new oceanic spreading centre is established. Early models incorporating melt into the evolution of the MER theorized that asthenospheric material is diapiracally emplaced into the lithosphere (Mohr, 1987). More recently, detailed multi-disciplinary investigation of the MER (e.g. Bastow et al., in press and references therein for a review) suggests lithospheric extension migrates from slip along rift border faults to focused dike intrusion and associated faulting on the rift floor (Ebinger and Casey, 2001; Casey et al., 2006).

The timing of initial extension in Ethiopia varies markedly along the length of the rift and three regions are recognized based upon the initial phase of rift border fault development (Fig. 1B). The timing of initiation of extension along the Red Sea and Gulf of Aden rift margins has been the subject of detailed stratigraphic (e.g. Bosworth et al., 1998; Fantzotti and Sgavetti, 1998), geochronologic (e.g. Hughes and Filatoff, 1995; Ukstins et al., 2002; Wolfenden et al., 2005), and magmatic studies (e.g. Camp and Roobol, 1989; Camp et al., 1991; Camp et al., 1992). While much uncertainty exists, a common conclusion of these studies is that extension along the Red Sea and Gulf of Aden margins occurred subsequent to the (30 $\pm 1 \mathrm{Ma}$ : Hofmann et al., 1997) initial plume
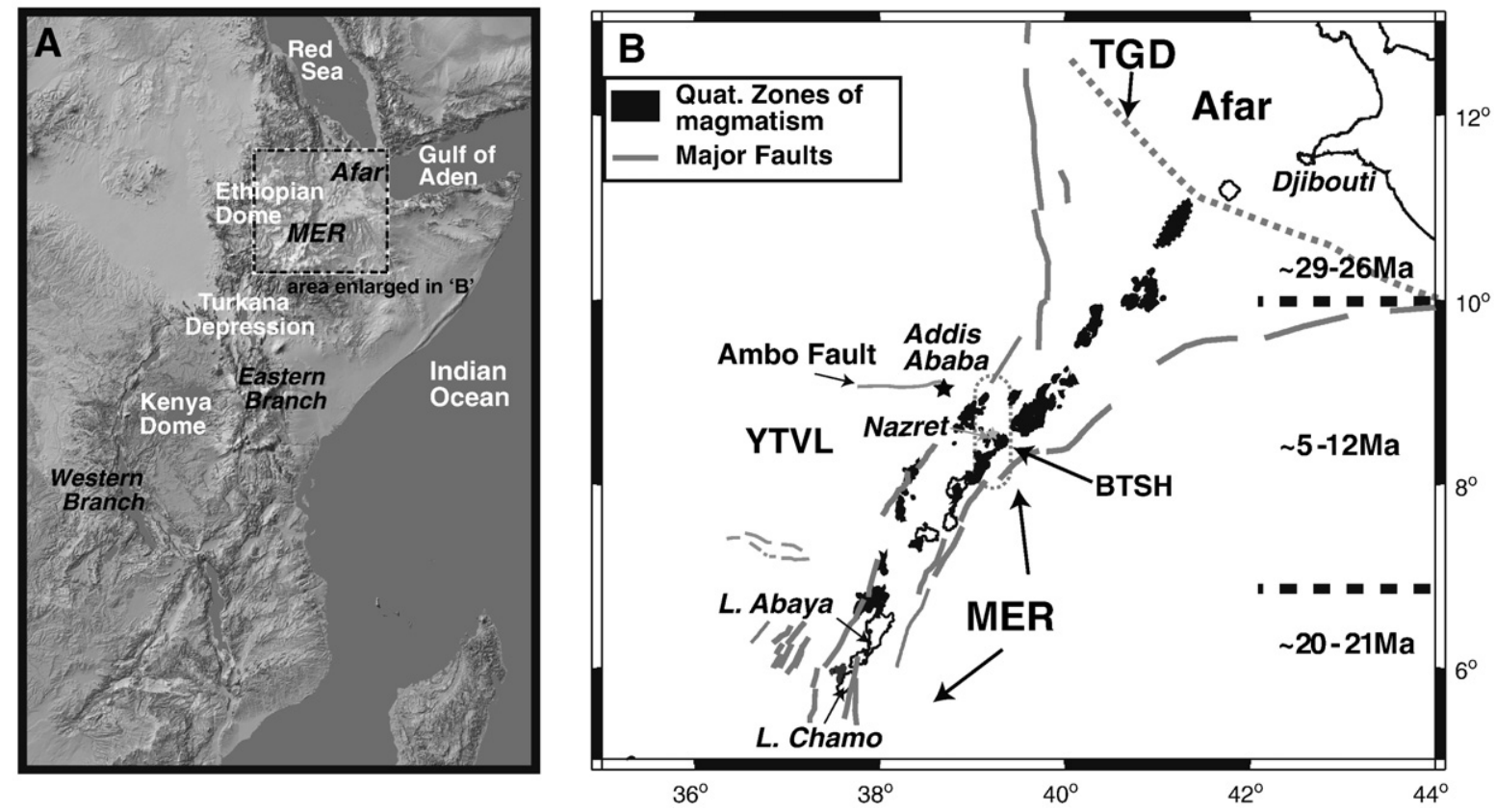

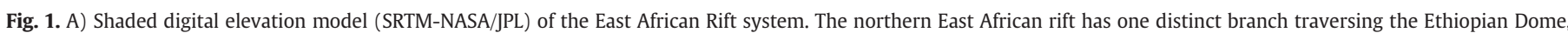

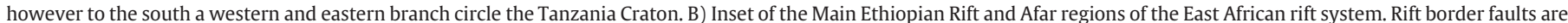

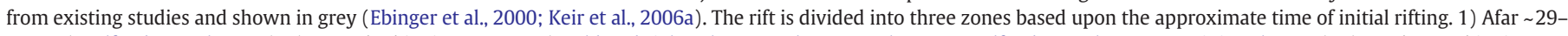

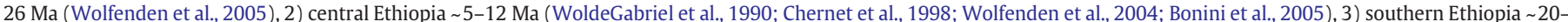

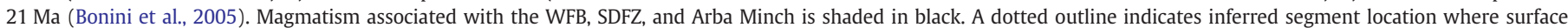

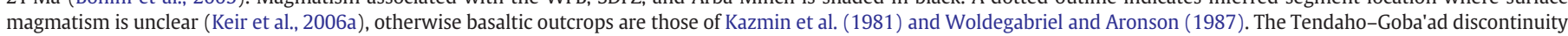
(TGD) is shown as a dotted grey line. Note that Quaternary magmatic activity outside of the WFB/SDFZ/Arba Minch regions is not shown (e.g. North of the TGD). 
volcanic event (see Bosworth et al., 2005 for more detailed discussion). In southern Ethiopia, the initiation of rifting is thought to be $\sim 18-20 \mathrm{Ma}$ (WoldeGabriel et al., 1990; 1991; Ebinger et al., 1993; Yemane et al., 1999; Bonini et al., 2005). The most recently rifted (5-12 Ma) portion of the Main Ethiopian Rift is in central Ethiopia between 7 and $10^{\circ} \mathrm{N}$ (Fig. 1: WoldeGabriel et al., 1990; Chernet et al., 1998; Wolfenden et al., 2004). Tectonic processes in the MER and Afar Depression continue to the present day in this seismically and volcanically active rift zone (Tadesse et al., 2003; Wright et al., 2006; Ayele et al., 2007; Keir et al., 2009b).

\subsection{Geophysical evidence of MER development}

The recent Ethiopia Afar Geoscientific Lithospheric Experiment (EAGLE: e.g. Bastow et al., in press) probed the region of transition from continental rifting to sea-floor spreading in the Ethiopian rift using passive and controlled source seismic techniques complemented by gravity and magnetotelluric studies. Results from EAGLE imply the presence of high seismic velocity (Keranen et al., 2004; Mackenzie et al., 2005; Maguire et al., 2006; Daly et al., 2008), high density (Tiberi et al., 2005; Cornwell et al., 2006; Mickus et al., 2007; Cornwell et al., 2010) crustal intrusions derived from a hot, partially molten upper mantle (e.g. Bastow et al., 2005; Bastow et al., 2008) with possible connection to the deeper African superplume (Ritsema and van Heijst, 2000; Grand, 2002; Benoit et al., 2006a; Benoit et al., 2006b; Montelli et al., 2006; Simmons et al., 2007; Li et al., 2008; Sicilia et al., 2008). High conductivity zones in the crust imaged by magnetotelluric study (Whaler and Hautot, 2006), and the spatial coincidence of seismicity in and around the MER with these zones of inferred partial melt (Keir et al., 2009a) point strongly towards ongoing magmatic processes in the region. Measurement of crustal thickness in the MER (Mackenzie et al., 2005; Maguire et al., 2006; Stuart et al., 2006; Cornwell et al., 2010) shows remarkably little crustal thinning, compared to predictions of stretching models with the implication that extension by magma intrusion may maintain crustal thickness during the later stages of breakup.

Studies of seismic anisotropy (e.g. Kendall et al., 2005; 2006; Bastow et al., 2010) show that the MER is one of the most anisotropic regions worldwide, with SKS splitting delay times as high as $\sim 3 \mathrm{~s}$. Intriguingly, the change in orientation of fast SKS waves from the plateau regions to the MER mirrors a shift from $\mathrm{N} 130^{\circ} \mathrm{E}$-directed extension to $\mathrm{N} 110^{\circ} \mathrm{E}$-directed extension at $\sim 2 \mathrm{Ma}$, when crustal strain localized towards the volcanically active Wonji Fault Belt (WFB) (e.g. Wolfenden et al., 2004), though recent studies have questioned such polyphase deformation (Corti, 2008) based upon revised kinematic models for Nubia-Somalia plate motion (Royer et al., 2006). Study of seismic anisotropy via combined analysis of body and surface waves shows that elongate melt inclusions (dikes and veins) characterise the Ethiopian lithosphere from $\sim 20 \mathrm{~km}$ to at least $50 \mathrm{~km}$ depth beneath the MER (Bastow et al., 2010).

\subsection{Initiation and development of magmatism associated with the MER}

The initial magmatic expression of extension has typically occurred along the rift margin where abundant silicic volcanoes (Wolfenden et al., 2004) and basaltic flows with unusual geochemical compositions (George and Rogers, 2002) are observed. In the central MER, abundant silicic volcanism along the rift flanks at 10-12 Ma, is coincident with the development of rifting in this region (Wolfenden et al., 2004). The Getra Kele basalts (19-11 Ma) near Arba Minch (Fig. 2) erupted synchronously with the initiation of rifting and are thought to represent a partial melt of the lithospheric mantle during initial lithospheric thinning (George and Rogers, 2002). Within the central MER, the earliest stages of volcanism are not well isotopically characterised, however in Afar, early rift volcanics (10-25 Ma) are well-exposed and geochemical studies have shown that these lavas have been substantially contaminated by the continental lithosphere (e.g. Deniel et al., 1994). Volcanism in the MER since the Late Miocene has been typically bimodal; silicic activity is by far the most dominant composition (e.g. Boccaletti et al., 1995; 1999a; Trua et al., 1999; Peccerillo et al., 2003). Large silicic volcanoes have developed on the rift floor and are typically located at the intersection of east-west striking faults with the more dominant northeast-southwest striking faulting in the rift (Korme et al., 2004; Abebe et al., 2007). The origin of these silicic centres has been linked to variations in strain rate, where the transition from silicic domes to basaltic cones coincides with an increased extension rate within the rift (Lahitte et al., 2003; Mazzarini et al., 2004). Increased extension, accommodated by crustal stretching, reduces the crustal thickness and may impact on magma transport through the lithosphere. The observed correlation between crustal thickness and the upper length-scale cutoff at which volcanic vents show self-similar clustering shows that the degree of crustal stretching fundamentally influences transport of basaltic magma from deep/subcrustal reservoirs to the surface (Mazzarini, 2007). In Afar, these large silicic centres developed as precursors to localized fissural basaltic volcanism along the axis of the rift (Lahitte et al., 2003). Away from these edifices, substantial volumes (up to $2000 \mathrm{~km}^{3}$ in a single eruption: WoldeGabriel et al., 1990) of ignimbrites, tuff, and volcanoclastic and lacustrine sediments cover the rift floor and deposition of these materials has continued to recent times (WoldeGabriel et al., 1990; WoldeGabriel et al., 2005; Brown and Fuller, 2008). As the locus of strain has migrated from rift border faults to seismically and volcanically active zones of extension on the rift floor (Ebinger and Casey, 2001; Buck, 2006; Casey et al., 2006), magmatism has become more restricted to small volume basaltic eruptions emanating from scoria cones and fissures located within the Wonji Fault Belt and Silti-Debre Zeyit Fault Zone (Figs. 1B, 2).

\section{Magmatic-tectonic fault belts in Ethiopia}

\subsection{Structural features of the Wonji Fault Belt}

The topographic expression of the northern MER is defined by $\sim \mathrm{NE}$ striking border faults that become more $\mathrm{N}-\mathrm{S}$ in the central and southern MER (Corti, 2009 and references therein) and have accommodated extensional strain during Miocene times (Wolfenden et al., 2004). However, since $\sim 2 \mathrm{Ma}$, the locus of extension has shifted in-rift to a $\sim 20$-km-wide zone of $\sim$ NNE striking Quaternary-Recent faults, fissures and chains of aligned volcanic cones (Ebinger and Casey, 2001). This Quaternary-Recent volcano-tectonic lineament was first described by Mohr $(1962 ; 1967 b)$ as the Wonji Fault Belt (WFB), and has been referred to in more recent literature as axial Quaternary magmatic segments (e.g. Ebinger and Casey, 2001; Keir et al., 2006a). The WFB has been interpreted as the onset of extension dominated by magma intrusion during the transition towards an oceanic spreading centre, where similar length-scale segmentation patterns are observed (Hayward and Ebinger, 1996; Ebinger and Casey, 2001; Keranen et al., 2004; Daly et al., 2008). The WFB defines a clear topographic feature from the Central MER to its sharp northerly termination at the Tendaho-Goba'ad discontinuity (Fig. 1: Tesfaye et al., 2003). The southern termination of the WFB is less well defined (Rooney, 2010). Within the central MER, the WFB is arranged in a right-stepping en echelon pattern, a geometry that may be kinematically imposed by the $\sim 40$-degree obliquity between the $\sim \mathrm{NE}$ striking Miocene border faults and the current $\sim \mathrm{E}-\mathrm{W}$ direction of extension (e.g. Corti, 2008). The obliquity between border faults and extension direction may therefore be a contributing factor to the manner in which strain localizes to a narrow zone as extension evolves (e.g. Corti, 2008; Agostini et al., 2009). Here, the WFB is offset towards the rift margins. In contrast, the northernmost $\sim 150 \mathrm{~km}$ of the WFB is set within the broad Afar depression where rifting initiated at $\sim 29-31 \mathrm{Ma}$ during extension in the southernmost Red Sea and westernmost Gulf of Aden rifts (Fig. 1) (Wolfenden et al., 2005; Ayalew et al., 2006). 


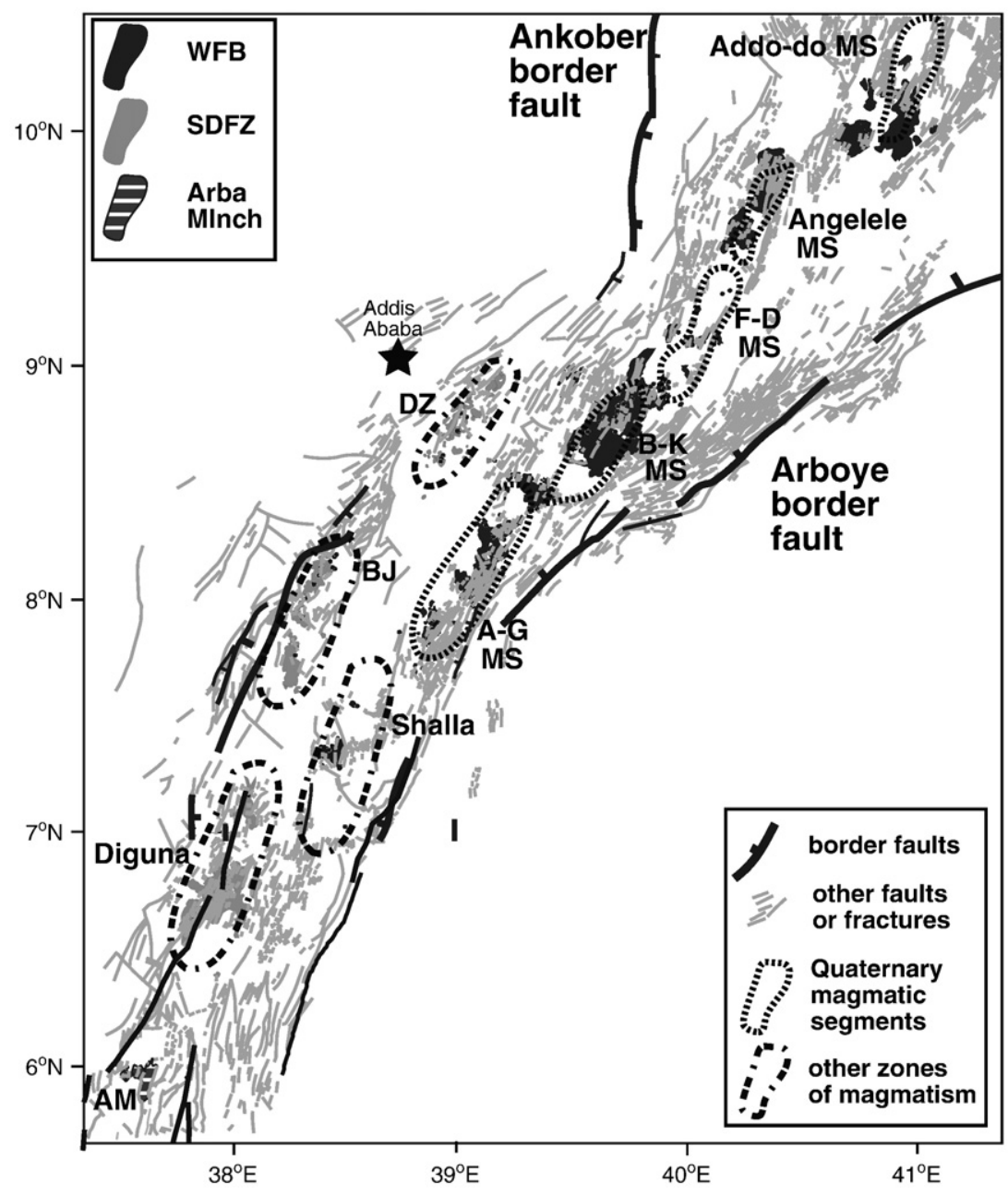

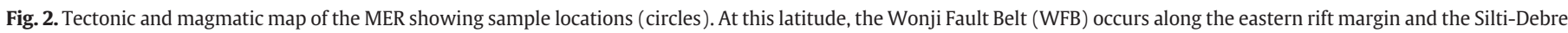

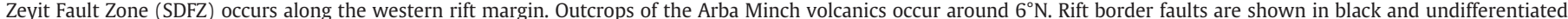

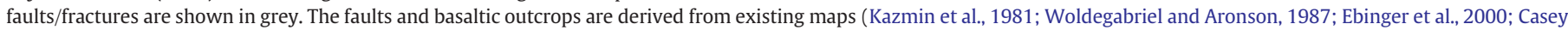

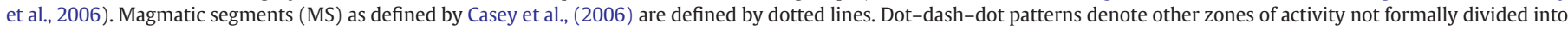
magmatic segments. F-D = Fantle-Dofan, B-K = Bosetti-Kone, A-G = Aluto-Gedemsa, DZ = Debre Zeyit, BJ = Butajira, AM = Arba Minch.

Here, the $\sim$ NNE striking WFB is relatively straight and not markedly offset to either the western or southern margins of the Afar depression. Recent geodetic studies have shown that $\sim 80 \%$ of extension within the MER is currently accommodated within the WFB (Bilham et al., 1999). In support of geodetic measurements of rift deformation, geophysical studies show that the WFB is a locus of seismicity concentrated in the upper $\sim 15 \mathrm{~km}$ of the crust (Keir et al., 2006a; 2006b). This relatively shallow brittle-ductile transition is broadly consistent with estimates of the elastic plate thickness in the MER derived from topography and gravity data (Ebinger et al., 1999; Tessema and Antoine, 2003; Perez-Gussinye et al., 2009).

The surface expression of the WFB is mirrored in subsurface geophysical data. The WFB is characterised by positive Bouguer anomalies (Tessema and Antoine, 2003; Tiberi et al., 2005; Cornwell et al., 2006) and underlain by anomalously high seismic velocity material interpreted as cooled mafic intrusions (Keranen et al., 2004; Daly et al., 2008). Keranen et al. (2004) and Daly et al. (2008) used local seismic tomography techniques to image a right-stepping pattern of high velocities between $20 \mathrm{~km}$ and $7 \mathrm{~km}$ depth in the crust beneath the
WFB. To first order, the geometry of the magmatic plumbing system in the upper crust beneath rift segments appears similar to that observed in mid-ocean ridges (e.g. Keranen et al., 2004). Numerical modeling suggests that once an elongate zone of diking is established in the rift axis, the strong, cooled mafic intrusions function to focus extensional stress and thereby promote emplacement of new dikes into the narrow zone of intrusion (Beutel et al., 2010).

Mantle structure beneath obliquely extending oceanic spreading segments mimics the en echelon lithospheric structure (e.g. van Wijk and Blackman, 2007); However beneath the WFB, the lowest seismic velocities do not directly underlie the Quaternary magmatic segments (Bastow et al., 2005; Bastow et al., 2008). Here the upper mantle is dominated by a NE-trending low velocity zone (75-100 km depth) that is offset towards the rift flanks, mimicking the initial fault controlled segmentation (Bastow et al., 2005; Bastow et al., 2008).The along-axis segmentation of the upper mantle, therefore, is not directly comparable to that reported at mid-ocean ridge spreading centres, where discrete zones of passively upwelling and partially molten asthenosphere underlie rift segments (e.g. Wang et al., 2009).

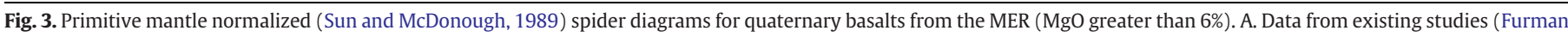

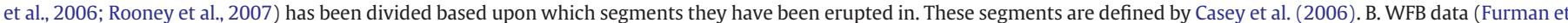

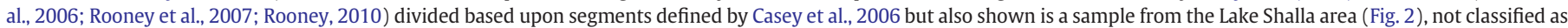

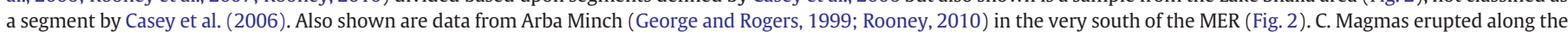
SDFZ are divided based upon locality of eruption and are grouped into three zones - see Fig. 2. Data are from Rooney et al. (2005) and Rooney (2010). 
A
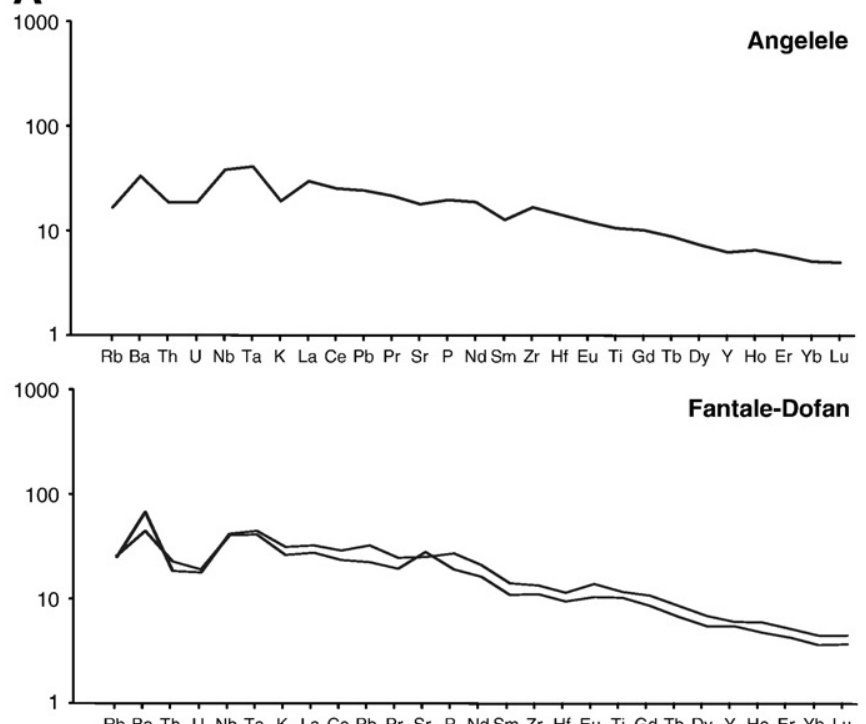

Rb Ba Th U Nb Ta K La Ce Pb Pr Sr P NdSm Zr Hf Eu Ti Gd Tb Dy Y Ho Er Yb Lu



B
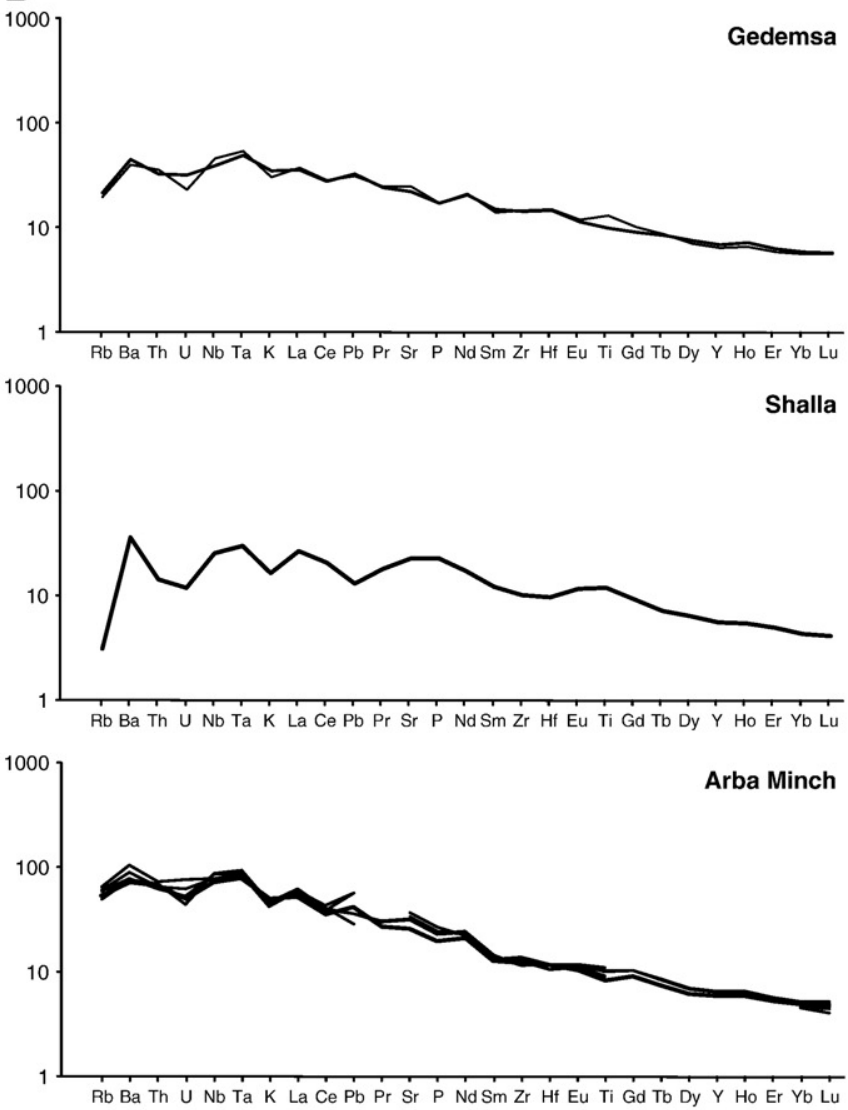
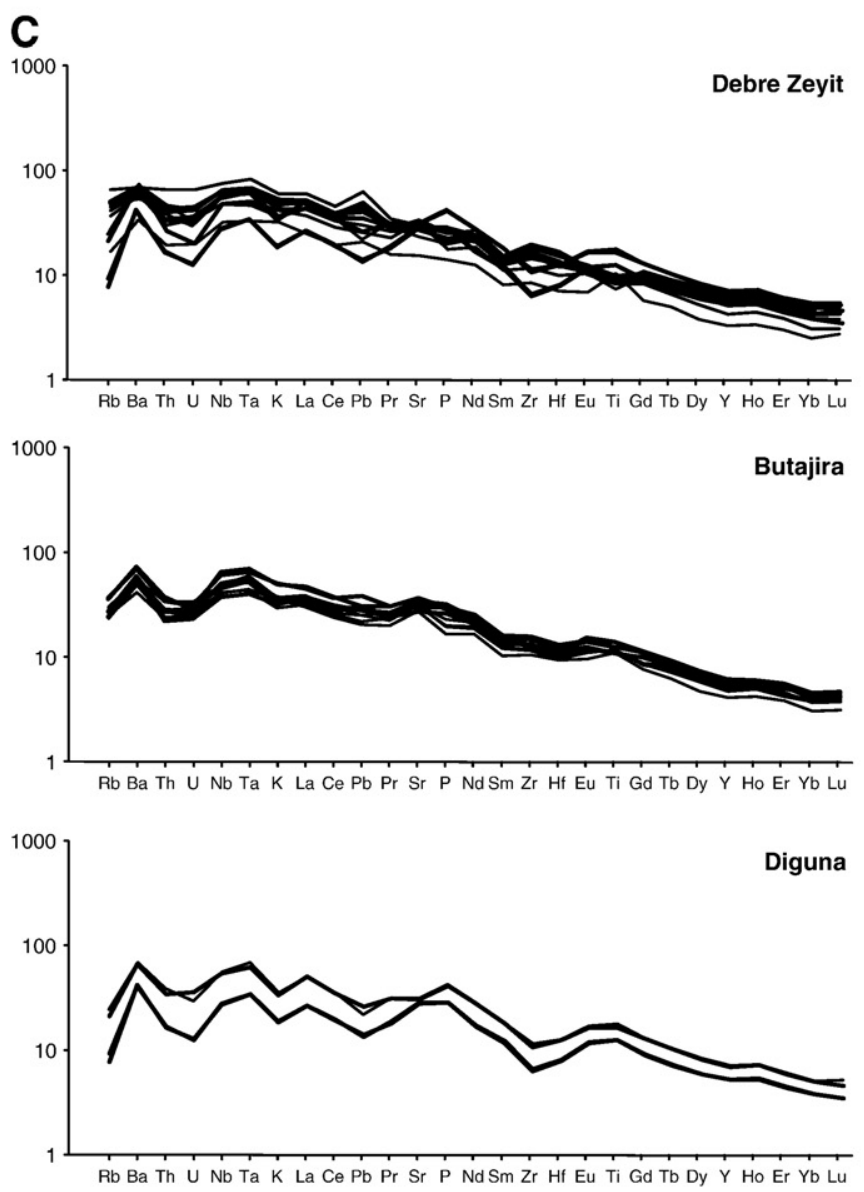


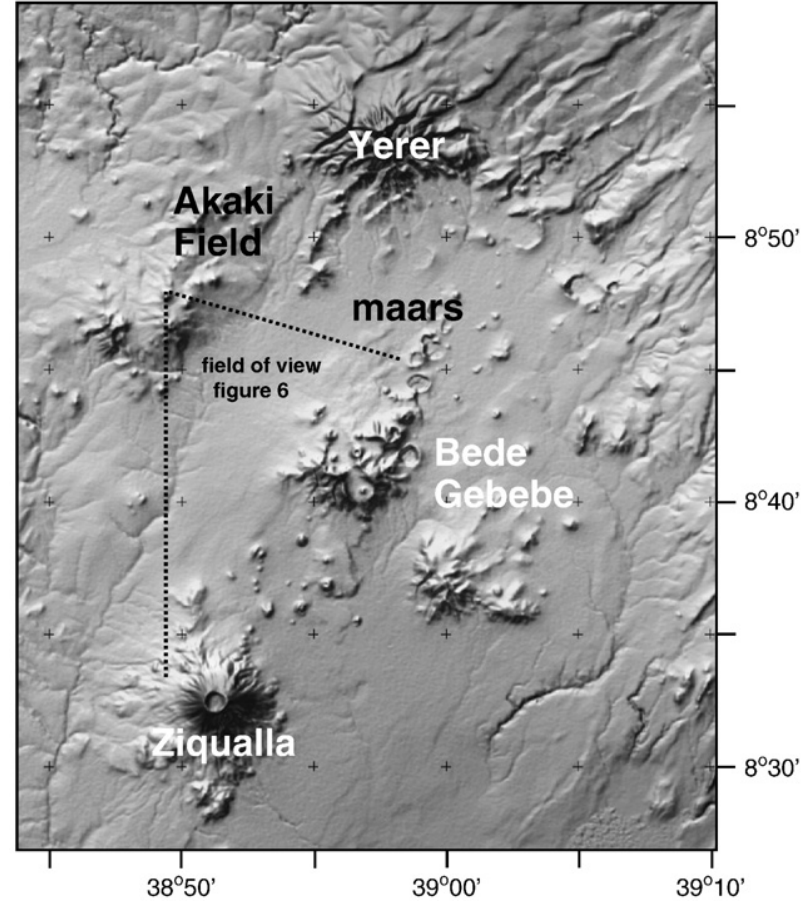

Fig. 4. Shaded DEM (SRTM - NASA/JPL) of the Debre Zeyit region of the SDFZ. Large silicic volcanoes are labeled (Yerer, Ziqualla, and Bede Gebebe). The Pliocene Akaki cinder cone field is shown adjacent to the SDFZ. The SDFZ terminates $\sim 9^{\circ} \mathrm{N}$ against a protrusion of the Ethiopian Plateau (Boru-Toru Structural High; Bonini et al., 2005). Note the abundance of cinder cones and maars along the alignment of the SDFZ which cut the earlier Bede Gebebe edifice.

The cause of obliquity between the $\sim$ NE striking rift border faults and NNE striking faults and aligned cones of the WFB remains controversial. One class of models suggests border faults formed within NW-SE extension during Miocene times, with a change to $\sim \mathrm{E}-$ W directed extension around $\sim 3.5 \mathrm{Ma}$ coeval with localisation of magma intrusion dominated strain to the WFB (Bonini et al., 1997; Boccaletti et al., 1999b; Wolfenden et al., 2004; Casey et al., 2006). Alternatively, Corti (2008) and Agostini (2009) used analogue models to show that the structural morphology of the central MER can be replicated using only $\sim \mathrm{E}-\mathrm{W}$ extension, with the $\sim \mathrm{NE}$ strike of the early rift border faults strongly influenced by similarly oriented pre-rift basement.

\subsection{Cindercones along the WFB}

Scoria cones and associated basaltic flows are the most visible feature of the WFB, occurring along its entire length and forming $\sim 2034 \mathrm{~km}^{2}$ (Abebe et al., 2007) of volcanic fields in the centralnorthern MER (Fig. 2). Faulting and associated magmatic activity in the WFB initially did not dissect earlier large silicic edifices built upon the rift floor. However silicic caldera complexes located within the WFB (e.g. Gedemsa) show evidence of dissection by subsequent faulting, and host small basaltic cones associated with and cut by these late-stage faults (Peccerillo et al., 2003). Throughout the WFB, scoria cones are dominantly located along faults and extensional fractures, frequently forming linear chains (e.g. Mohr, 1967b). Favourable stress conditions that develop at fault tips are thought to facilitate magma ascent and scoria cone eruption (Casey et al., 2006). In the Kone region of the central MER, 51\% of all faults have an associated eruptive centre, with scoria cones focused at fault tips and open cracks (Casey et al., 2006). Scoria cones are found in various states of preservation within the WFB (both in terms of natural erosion and mining for aggregate) but are particularly fresh around the Bosetti-Fantale region where a magma fissuring event occurred in the 19th Century (Mohr, 1962; Williams et al., 2004), and $1587 \mathrm{~km}^{2}$ of magmas have been erupted (Abebe et al., 2007).

\subsection{Geochemistry of WFB segments}

The spatial extent of the WFB segments has previously been defined from the surficial lateral continuity of magmatism and faulting (Fig. 2) (Mohr, 1967b; Ebinger and Casey, 2001; Casey et al., 2006; Kurz et al., 2007). These continental segments have been compared to the segmentation observed at mid-ocean spreading centres based upon some similarities in lithospheric structure (e.g. Keranen et al., 2004), though the mantle beneath the rift has yet to organise into punctuated upwellings (Bastow et al., 2005; 2008). Geochemical labelling has proved particularly effective in defining oceanic ridge segmentation (e.g. Sinton et al., 1991). We have taken the most primitive $(>6 \% \mathrm{MgO}$ ) lavas erupted within the segments defined by Casey et al. (2006) and present a comparison of the geochemical characteristics of the volcanic products (Fig. 3). Recent geochemical studies have indicated that Ethiopian rift mafic magmas have been derived from three sources: the Afar plume, the local asthenospheric mantle, and the continental lithosphere (Deniel et al., 1994; Furman et al., 2006). Magmas erupted along the WFB exhibit similar patterns defined broadly by positive $\mathrm{Ba}, \mathrm{Nb}$ and $\mathrm{Ta}$ anomalies

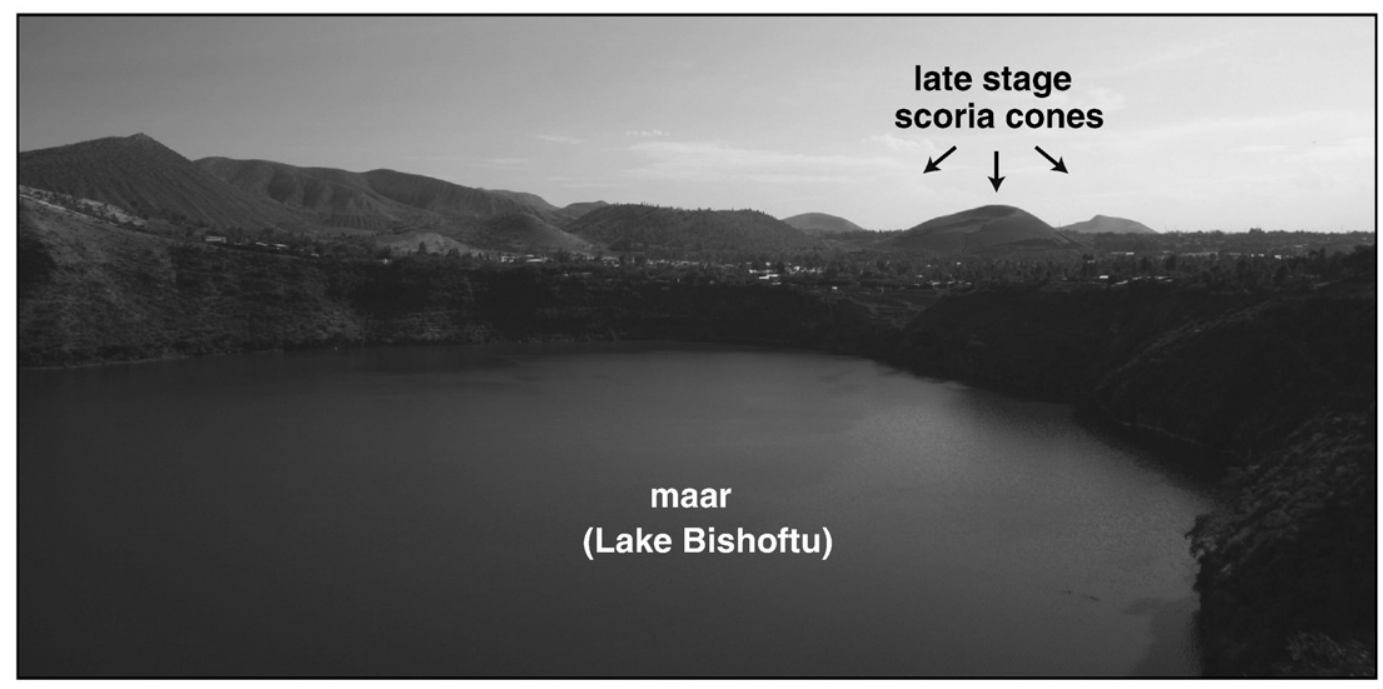

Fig. 5. Photo of a maar (Lake Bishoftu) in the Debre Zeyit area $\left(\sim 8^{\circ} 40 \mathrm{~N} ; 38^{\circ} 55 \mathrm{E}\right)$ with surrounding scoria cones. 
and a Th-U trough (Figs. 3A,B), suggesting some similarities in their magmatic sources. This pattern is particularly pronounced in the Angelele, Fantale-Dofan, Kone-Bosetti, and Shalla segments. Magmas erupted within the Gedemsa segment are similar to others along the WFB, however the anomalies are more suppressed and bear some resemblance to magmas erupted at Arba Minch. These patterns may relate to mixing between silicic and basaltic magmas, consistent with petrologic evidence of magma mixing at both locations (George and Rogers, 1999; Peccerillo et al., 2003; Rooney, 2010).

\subsection{Silti-Debre Zeyit Fault Zone}

The Silti-Debre Zeyit Fault Zone (SDFZ) has always played a minor role in discussions of rift volcanism in the MER, though it forms a volumetrically significant region of Quaternary magmatism along the western rift margin (WoldeGabriel et al., 1990; Rooney et al., 2005). Abundant scoria cones and associated flows (373-732 $\mathrm{km}^{2}-$ range dependant on definition of SDFZ) occur in linear chains along the SDFZ. However unlike the WFB, the surface expression of faulting and fracturing is not well-developed (Kurz et al., 2007). The SDFZ was initially considered to be $\sim 100 \mathrm{~km}$ long and $2-5 \mathrm{~km}$ wide (WoldeGabriel et al., 1990), terminating to the north against an embayment of the rift margin at $9^{\circ} \mathrm{N}$ (Fig. 4). However, the southern limit is complicated by possible overlap between the WFB and SDFZ at $6.5-7^{\circ} \mathrm{N}$ (WoldeGabriel et al., 1990; Rooney, 2010). In this overlap region, magmas have trace element characteristics similar to those found further north along the SDFZ but abundant surface faulting similar to the WFB is evident (Rooney, 2010). We propose that within the central MER, PlioQuaternary volcanism occurring along the eastern rift margin be attributed to the WFB while activity along the western rift margin be recognized as the SDFZ. On this basis, the SDFZ becomes a significantly longer feature extending from $6.5^{\circ} \mathrm{N}$ to $9^{\circ} \mathrm{N}$.

\subsection{Cindercones and maars along the SDFZ}

An important distinction between the WFB and SDFZ is the presence of abundant explosion craters in the Debre Zeyit and Butajira and regions of the SDFZ, which are more limited along the WFB (Fig. 2). At least 16 explosion craters (Fig. 5) have been identified in Debre Zeyit and three in the Butajira portion of the SDFZ (Mohr 1961). These craters have steep sides and flat bottoms, are frequently aligned and exhibit diameters close to $1 \mathrm{~km}$ that sometimes intersect (Mohr, 1961). The craters were generated during the same phase of activity that has produced cinder cones and flows in the region (Mohr, 1967a). The alignment of the craters also coincides with the eruption of some cinder cones (Figs. 4, 5). While some early discussion centred on a possible meteorite impact (Sjogren, 1951), the origin of the Debre Zeyit explosion craters is clearly volcanic and related to maar formation (Mohr, 1967a; Gasparon et al., 1993). Early reconnaissance work interpreted the presence of 'solvsbergite' blocks within the maar ejecta as evidence for a carbonatitic magma source (Mohr, 1961; 1967a). While these blocks have not been examined with modern techniques, magma from adjacent cinder cones shows no evidence for carbonatitic metasomatism in its mantle source (Rooney et al., 2005). Similar to the WFB, large silicic centres and complexes occur in the Debre Zeyit region (Fig. 6) of the SDFZ (e.g. Ziqualla 1.3-0.9 Ma:
Morton et al., 1979) that on occasion may be heavily dissected by later basaltic activity (e.g. Bede Gebebe: Gasparon et al., 1993).

\subsection{Geochemistry of SDFZ}

The SDFZ is broadly divisible into three groups based upon geographic distribution of Plio-Quaternary magmas: Debre Zeyit, Butajira, and Diguna (Fig. 2). The overall trace element pattern in all three regions of the SDFZ is similar and resembles the WFB with prominent $\mathrm{Ba}, \mathrm{Nb}$ and Ta peaks and a Th-U trough. At Diguna, a peak in $\mathrm{P}$ coupled with a depletion in $\mathrm{Zr}-\mathrm{Hf}$ has been interpreted as minor apatite in the source of these magmas (Rooney, 2010). The same patterns are also observed in some of the Debre Zeyit samples. While the SDFZ and WFB lavas are likely derived from similar mantle sources, the mantle beneath the SDFZ may have underwent minor metasomatism of unknown origin (Rooney, 2010).

\subsection{Arba Minch volcanics}

Quaternary volcanism and faulting in the Arba Minch region of southern Ethiopia (also known as the Bobem, Tosa Sucha or Nech Sar Basalts: Levitte et al., 1974; Zanettin, 1978; George and Rogers, 1999; Abebe et al., 2007; Rooney, 2010) broadly resembles activity in the WFB and SDFZ. Flows within this smaller basaltic field ( $163 \mathrm{~km}^{2}$; Abebe et al., 2007) frequently directly overlie the Pan-African basement (George and Rogers, 1999) or the Amaro tuffs (Ebinger et al., 1993). Mt. Bobem, which forms a barrier between Lake Abaya and Lake Chamo, is the most significant volcanic edifice in the region, and has been faulted and intruded similar to the silicic centres further north (Ebinger et al., 1993). While initially associated with the WFB (Mohr, 1962), the Arba Minch volcanics do not share the same geochemical characteristics as the SDFZ and WFB to the north (Rooney, 2010) and therefore is treated separately here (Fig. 3B). Ebinger et al., (1993) have suggested that the occurrence of the most recent rift activity in a narrow $10 \mathrm{~km}$ zone on the rift floor in the Arba Minch region reflects the basinward migration of strain during the Quaternary.

The geochemical characteristics of the Arba Minch volcanics are different to the WFB and SDFZ, exhibiting a much more significant enrichment in the most incompatible trace elements (Fig. 3B). While some assimilation and magma mixing has been invoked (George and Rogers, 1999; Rooney, 2010), the unusually radiogenic Pb isotope signature of the Arba Minch suite in comparison to the WFB (Fig. 7), suggests differences in the mantle sources contributing to the Arba Minch volcanics. The precise origin of this heterogeneity is the subject of ongoing isotopic studies.

\section{Relationship between extension and magmatism in the Main Ethiopian Rift}

\subsection{Diking induced fracture}

The observed association between magmatism (e.g. aligned scoria cone fields) and extensional tectonic features (faulting/fracturing) in the MER has recently been attributed to dike induced faulting in the crust (e.g. Casey et al., 2006; Kurz et al., 2007; Rowland et al., 2007). In one version of this model, magma ascent from the mantle into the

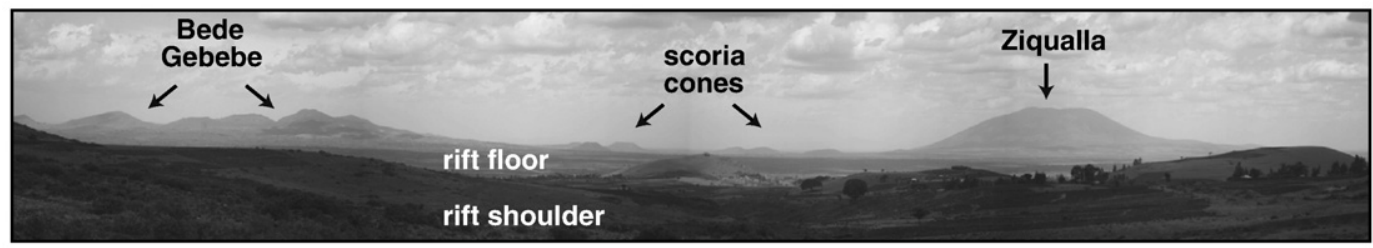

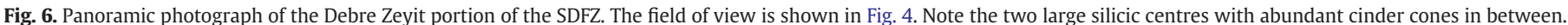






Fig. 7. Pb isotope plot of the WFB (Furman et al., 2006) and Arba Minch volcanics (George and Rogers, 1999). Other regional data sets are shown for comparison: agecorrected 30 Ma LT flood basalts (Kieffer et al., 2004) and the 30 Ma HT2 flood basalts (Pik et al., 1999). Shown for reference is the Northern Hemisphere Reference Line (NHRL: Hart, 1984), "C" mantle reservoir (Hanan and Graham, 1996), EM1 and EM2. Note the Arba Minch samples extend to much higher values of ${ }^{206} \mathrm{~Pb} /{ }^{204} \mathrm{~Pb}$ in comparison to the WFB.

crust is focused to a magmatic plumbing system at the centre of the magmatic segments. Such segment-centred magmatic systems feed dikes emplaced laterally along the rift axis (Kurz et al., 2007). Concentrated tensional stress near the leading edge of an intruding dike induces surface fracturing/faulting (e.g. Rubin and Pollard, 1988; Rubin, 1990). Faulting observed in the WFB may therefore propagate upward from mid-upper crustal zones of intrusion (Casey et al., 2006). The majority of seismic moment along the rift axis is released during dike injection; thereby supporting a model of dike induced normal faulting (Wright et al., 2006; Keir et al., 2009b). A shared conclusion of these models is that magma intrusion now controls extension in the MER, and that the MER is comparable to other more developed rifts such as Iceland (e.g. Casey et al., 2006).

This model of magma ascent and intrusion from a segment centre is testable by utilizing the geochemical characteristics of magmas erupted within a magmatic segment. Specifically, magmas that have not been influenced by fractionation or assimilation should not differ in terms of their geochemical characteristics. There are significant isotopic and geochemical variations within individual magmatic segments of the WFB and SDFZ that cannot be attributed to assimilation and fractional crystallisation processes (Rooney et al., 2005; Furman et al., 2006; Rooney et al., 2007; Rooney, 2010). At Kone, an unusual group of magmas with major, trace element and isotopic heterogeneity have been interpreted to be derived from a different (possibly deeper) source to other magmas in the segment (Furman et al., 2006), complicating a central magma ascent hypothesis. A possible mechanism by which these geochemical heterogeneities could be accommodated within a model of a segmented rift would be to interpret the heterogeneity in the geochemical compositions of magmas in terms of temporal variations in magmas ascending into the upper crust. With current data density it is not possible to fully assess this model and future studies are required.

\subsection{Fracture-induced normal faulting}

An alternate group of geodynamic models have focused on fissuring and fractures and suggested that dilatational fractures/ fissures that develop in the upper crust during extension propagate downwards into the lithosphere (Acocella et al., 2003; Williams et al., 2004). When the tensile limit of the lithosphere is reached ( $750 \mathrm{~m}$ in the MER) these fractures become normal faults (Acocella et al., 2003). Fracture-induced normal faulting models do not require the presence of magma or dike intrusion. Based upon this model, open structures such as tail-cracks, releasing bends, extensional relay zones, and fault intersections may simply act as conduits allowing magmas ascend to the surface to form aligned chains of cinder cones (Chorowicz et al., 1994; Korme et al., 1997; 2004). The location of monogenetic cinder cones along linear features such as tail-cracks leads to the development of elongated cones and breaching of the craters sympathetic to the linear features beneath (Korme et al., 2004).

\subsection{Magmatic fractionation systems - WFB}

The geochemical characteristics of the MER magmas impose important constraints in deducing the relationship between mechanical extension and magmatism; however, these data have not been incorporated into earlier geodynamic models. Numerous studies have examined the geochemical characteristics of Quaternary magmatism within the WFB, focusing on the issue of assimilation and fractional crystallisation of the basalts and the magmagenesis of the silicic products in the rift (Cole, 1969; Dickinson and Gibson, 1972; Weaver et al., 1972; Brotzu et al., 1974; Gibson, 1975; Brotzu et al., 1981; Gasparon et al., 1993; Webster et al., 1993; Boccaletti et al., 1995; Boccaletti et al., 1999a; Trua et al., 1999; Peccerillo et al., 2003; Peccerillo et al., 2007; Rampey et al., 2010; Ronga et al., 2010). A full review is beyond the scope of this paper, though basalts erupted in the WFB are among the least crustally contaminated in the region (e.g. Furman et al., 2006; Rooney et al., 2007; Rooney, 2010). However, in some locations the assimilation of existing magmatic cumulates does produce distinctive compositions (e.g. Fantale: Rooney et al., 2007). Excluding samples affected by these lithospheric processes, magmas along the length of the WFB exhibit differences in major and trace elements, and radiogenic isotopes that vary over the length scales of adjacent scoria cones. Parental magma heterogeneity is particularly evident in lavas erupted along the Bosetti-Kone segment (Figs. 2;3). In this segment, a group of basalts exhibiting substantially elevated normative nepheline also display enriched incompatible trace elements and radiogenic $\mathrm{Pb}$ isotopes in comparison to other KoneBosetti magmas (e.g. Furman et al., 2006). The wide range in $\mathrm{Tb} / \mathrm{Yb}$ values of basalts erupted throughout the Kone-Bosetti segment (Fig. 9) also requires multiple parental magmas. These observations have implications for the length scale of melt extraction and magmatic plumbing system in the MER (see Section 5.4).

Recently, detailed analysis of basaltic volcanism along the WFB has generated constraints on the depth of magma generation, the structure of the magmatic plumbing system and the apparent connection between magmatism and extension in the MER (Trua et al., 1999; Furman et al., 2006; Rooney et al., 2007; Rooney, 2010). Petrographic modeling, thermodynamic modeling and single clinopyroxene pressure estimates have shown that the WFB magmas initially pond and fractionate at lower crustal levels but ascend and predominantly fractionate in the upper crust (Trua et al., 1999; Rooney et al., 2007; Rooney, 2010). There appears to be little if any variation in these fractionation depths along the WFB within the central MER. The predominantly shallow fractionation sequence observed in the WFB is consistent with models of dike injection in volcanic rift zones with a high magma supply rate (Behn et al., 2006).

\subsection{Magmatic fractionation systems in the SDFZ}

Though adjacent to the WFB, the magmatic plumbing system of the SDFZ exhibits geochemical characteristics indicative of fractionation at deeper levels within the crust. Major and trace element variations of the SDFZ lavas are best interpreted by the increased removal of clinopyroxene over plagioclase during fractionation at mid to lower crustal levels (Rooney et al., 2007; Rooney, 2010). The phenocryst assemblage of the SDFZ lavas includes abundant clinopyroxene, plagioclase, skeletal olivine and numerous gabbroic xenoliths 
and megacrysts (Rooney et al., 2005). Individual pressure estimates of the clinopyroxene phenocrysts and xenocrysts suggest a complex fractionation system that is spread widely throughout the mid-lower crust (Rooney et al., 2005). Megacrysts frequently exhibit chemical disequilibrium with the host magma composition and are interpreted to have been derived from an earlier phase of magmatism that stalled in the crust (Fig. 8). The origin of this earlier phase of magmatism remains unclear and it may be connected with magmatic underplating resulting from Oligocene plume-lithosphere interaction (Rooney et al., 2005), or magma accumulation at the base of the crust near the rift border faults (Bonini et al., 2001). Magmas in the SDFZ have re-used these earlier magmatic conduits and ripped the more-evolved megacrysts and xenocrysts from these dike walls (Rooney et al., 2005). The typically deeper fractionation sequence observed within the SDFZ in comparison to the WFB is consistent with models of dike injection in volcanic rift zones with a low magma supply rate (Behn et al., 2006). This magma supply association is strengthened by the greater degree of rift subsidence along the WFB; numerical models have suggested that rift valleys subside more rapidly when dikes are shallowly emplaced (Behn et al., 2006).

The geochemical characteristics of basalts erupted from scoria cones along the SDFZ show that many share the same broad geochemical features, however the range in major and trace element compositions precludes derivation from the same parental magma (Rooney et al., 2005). Importantly, trace element ratios insensitive to gabbroic fractionation (e.g. Tb/Yb; Rooney 2010) exhibit regular variation with latitude along the length of the SDFZ, and imply that magmas sample the mantle beneath the SDFZ on length scales of individual scoria cones, precluding the derivation of magmatism along the SDFZ by magma ascent in a central conduit.

\subsection{Correlations between fractionation systems and surface expression of faulting}

The emplacement of basaltic dikes into the continental lithosphere during the Pliocene-Quaternary had profound impact on the morphology and topography of the rift. As extension became focused within the WFB and to a lesser extent the SDFZ (Ebinger and Casey, 2001; Buck, 2006), normal faults such as the rift border faults became suppressed (e.g. Parsons and Thompson, 1991). Faulting and fracturing however were still apparent within the newly focused zones of intrusion (e.g. Casey et al., 2006). The observations presented above show a strong linkage between shallow magmatic fractionation conditions and the surface expression of faulting and fracturing. A corollary is that even in regions where fractionation conditions are deeper (e.g. SDFZ), linear magmatic chains are also observed. Downward propagating fracture models (e.g. Acocella et al., 2003) do not easily account for this observed correlation and typically assume processes active within the SDFZ mirror the WFB. These models have explained linear chains of scoria cones at the surface of the SDFZ as the result of unseen extensional fractures (e.g. Korme et al., 1997), without comment as to possible differences between the SDFZ and WFB.

Recently, studies of dike emplacement in northern Afar have observed the processes associated with lithospheric extension through magmatic intrusion in a rifting environment (Keir et al., 2009b). This model assumes parental magma batches rise at the centre of spreading segments into the upper crust and then radiate laterally outward, similar to processes active within a oceanic spreading centre. Stresses at the dike margins fracture the lithosphere, which then propagate upwards to the rift floor. The observed correlation of shallow fractionation conditions and intense surface faulting supports a model whereby magmas are emplaced and fractionate close to the surface and induce surface faulting (i.e. WFB). In regions where faulting/fracturing is absent, magmas are intruded and evolve at deeper crustal levels and therefore do not



Fig. 8. Previously published cartoon (Rooney et al., 2007) comparing the magmatic plumbing system of the SDFZ and WFB.

induce surface fractures (i.e. SDFZ). Alternatively, the lower degree of extension accommodated within the SDFZ may suppress fracture development thereby reducing the number of conduits available to channel magma to the surface.

\section{Lithospheric thinning as deduced from magmatism}

\subsection{Lithospheric thinning in the rift as a function of time}

The initiation and evolution of extension in continental rifts is recorded by thinning of the continental lithosphere (Ebinger and Casey, 2001). During the early stages of rifting, extension by lithospheric thinning of the $\sim 100 \mathrm{~km}$ thick (Dugda et al., 2007) African plate likely induced asthenospheric upwelling resulting in thermal anomalies, and appreciable volumes of partial melt beneath the rift. As the locus of strain shifted during the Quaternary, narrow zones of magma intrusion developed in the significantly thinned rift lithosphere. Asthenospheric upwelling would be expected to reduce after initial plate stretching with a resulting reduction in the volumes of melt produced in response to extension. In support of this observation, SKS-splitting studies of seismic anisotropy show that the zones of most concentrated partial melt occur in central Ethiopia (e.g. Kendall et al., 2006; Bastow et al., 2010), coincident with the region of most recent plate stretching. The MER around $9^{\circ} \mathrm{N}, 39^{\circ} \mathrm{E}$ is also site of the largest vertical asthenospheric flow rate in Ethiopia inferred by studies that predict global mantle flow (Forte et al., 2010). Geophysical techniques provide an excellent method to examine instantaneous variations of lithospheric thickness, however the geochemical characteristics of rift basalts preserve a temporal record of thinning. Basalts erupted in continental rifts are typically assumed to be derived from melting zones located dominantly within the asthenosphere. The depth extent of this melting column may vary, however the top of the melting column is generally considered to be the base of the rigid lithosphere (Wang et al., 2002; Ayalew and Gibson, 2009; Rooney, 2010). Initially, melt is generated within the garnet-lherzolite stability field but as the lithosphere is thinned during extension, the melting column will become progressively shallower and more melt will be generated within the spinellherzolite field. An important geochemical consequence of this transition is a decrease in the fractionation of the middle and heavy rare earth elements (e.g. $\mathrm{Tb} / \mathrm{Yb}$ ) as garnet becomes less abundant in the melt source. A detailed study of lithospheric thickness variations 


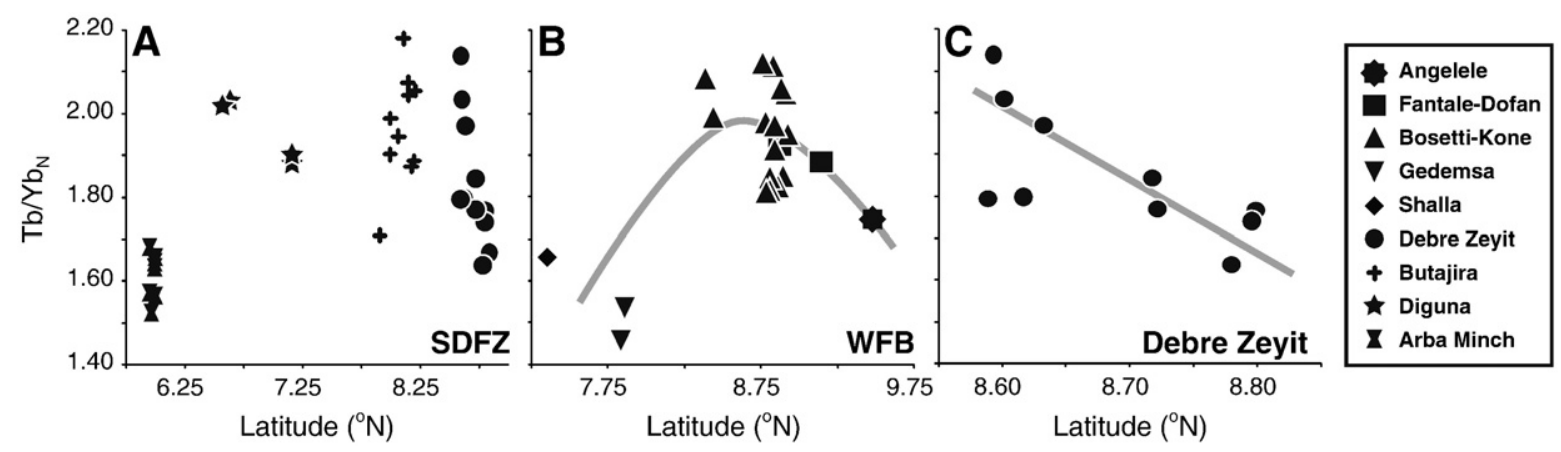

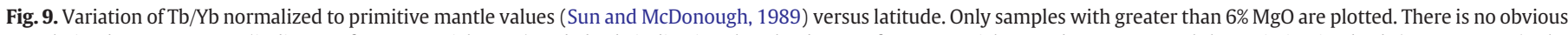



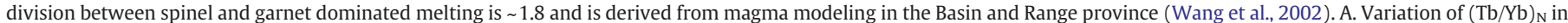



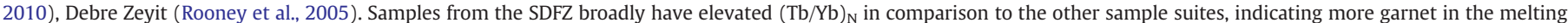

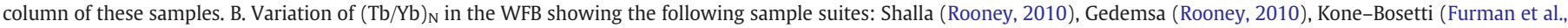

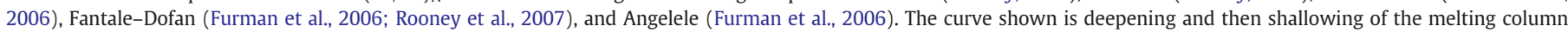

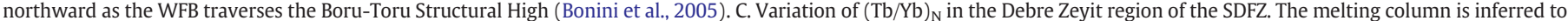
shallow northwards.

in the MER is presented elsewhere (Rooney, 2010) but some key points are presented here. In the Arba Minch region of the MER, basalts erupted during the initiation of rifting (19-11 Ma: Zanettin, 1978; George et al., 1998; Ebinger et al., 2000) have trace element characteristics that infer a deeper mantle source in comparison to modern basalts erupted on the rift floor (Fig. 9). These results have been interpreted as the thinning of the lithosphere during rift evolution (Figs. 10;11), though the precise timing remains poorly constrained due to the lack of basaltic magmatism in the region between $11 \mathrm{Ma}$ and the present day.

\subsection{Lithospheric thinning in the rift as a function of latitude}

To examine the relationship between rift development and lithospheric thinning, we explore the variability in $\mathrm{Tb} / \mathrm{Yb}$ along the axis of the rift. In the MER, the Arba Minch area has some of the shallowest inferred melting columns (and by extension the greatest degree of lithospheric thinning). This region is at the eastern edge of a broadly rifted zone in southern Ethiopia that accommodated extension from Oligocene-Recent times (e.g. Moore and Davidson, 1978; Davidson and Rex, 1980; Woldegabriel and Aronson, 1987; Ebinger et al., 2000). In the MER, the WFB south of $8^{\circ} \mathrm{N}$ exhibits geochemical characteristics that suggest a melting column at depths similar to Arba Minch, however the source heterogeneity inferred between the two regions (Fig. 7) prevents a precise comparison. As the WFB impinges on the Boru-Toru Structural high at $\sim 8^{\circ} \mathrm{N}$, the sudden increase in $\mathrm{Tb} / \mathrm{Yb}$ values are interpreted as an increase in the depth of the melting column. The presence of this structural high, which has only recently been breached by the WFB (Bonini et al., 2005; Rooney et al., 2007), coincides with increased lithospheric thickness and a correspondingly deeper melting column. Further north, magmas erupted in the Fantale-Dofan and Angelele magmatic segments (away from the Boru-Toru Structural High) have $\mathrm{Tb} / \mathrm{Yb}$ values that show the melting column depth becomes progressively shallower, consistent with a longer history of African-Arabian extension.

Melting column depths within the SDFZ are inferred to have a more significant contribution from within the garnet lherzolite field, and extend to greater depths in comparison to the WFB (Fig. 9). A significant departure occurs in the Debre Zeyit region of the SDFZ where $\mathrm{Tb} / \mathrm{Yb}$ values (and inferred lithospheric thickness) decrease rapidly northward (Fig. 9). This result is unexpected, as it would imply that the thinnest lithosphere occurs as the SDFZ terminates against the Boru-Toru Structural High (Fig. 4). A possible explanation to this anomalous behaviour may be the intersection of the Yerer-Tullu Wellel volcano- tectonic lineament (YTVL: Abebe et al., 1998; Rooney et al., 2007) with the rift margin at this latitude. The rift margin adjacent to the northern termination of the SDFZ does not exhibit significant border faulting, and instead hosts a chain of Pliocene cinder cones (Akaki Chain; Fig. 4). Further study of this margin is needed, however the existence of an older phase of aligned scoria cones adjacent to the northern SDFZ may imply an earlier phase of lithospheric thinning associated with the YTVL (e.g. Keranen and Klemperer, 2008). An important implication of the observed correlation between melting column depth in zones of focused magmatic intrusion and lithospheric thickness, is that lithospheric structures initially control the development of upper mantle melting zones. The retention of heterogeneities related to depths of mantle melting during the terminal stages of rifting may impact the subsequent development of oceanic spreading segments. While the extent to which pre-existing lithospheric structures controls the subsequent development of segmentation remains unclear, this model outlines a viable mechanism.

\subsection{Lithospheric thinning as a function of position in the rift}

Variation in the depth of the melting column of rift basalts is evident across the rift between the SDFZ and WFB. Away from the

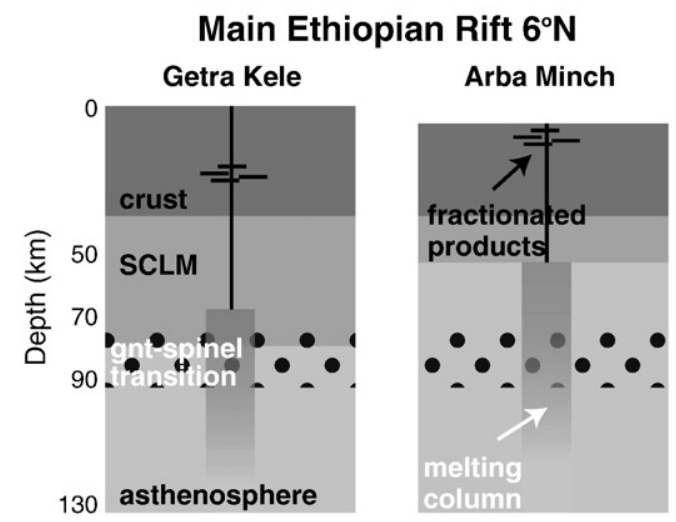

Fig. 10. Cartoon showing the shallowing of the melting column during progressive rift evolution at Arba Minch (reprinted from Rooney 2010). The lower depth extent of the melting column is derived broadly from Ayalew and Gibson (2009) who suggest melting beneath the modern Main Ethiopian Rift is incipient from 130 to $100 \mathrm{~km}$. The depth range of the garnet to spinel transition (dots) is also derived from the study of Ayalew and Gibson (2009). The geometry of the melting column is uncertain and is illustrated here as a box simply to highlight the different depth extents of melting. Inferred lithospheric thicknesses are derived from geophysical studies (Dugda et al., 2005; Mackenzie et al., 2005; Tiberi et al., 2005). 


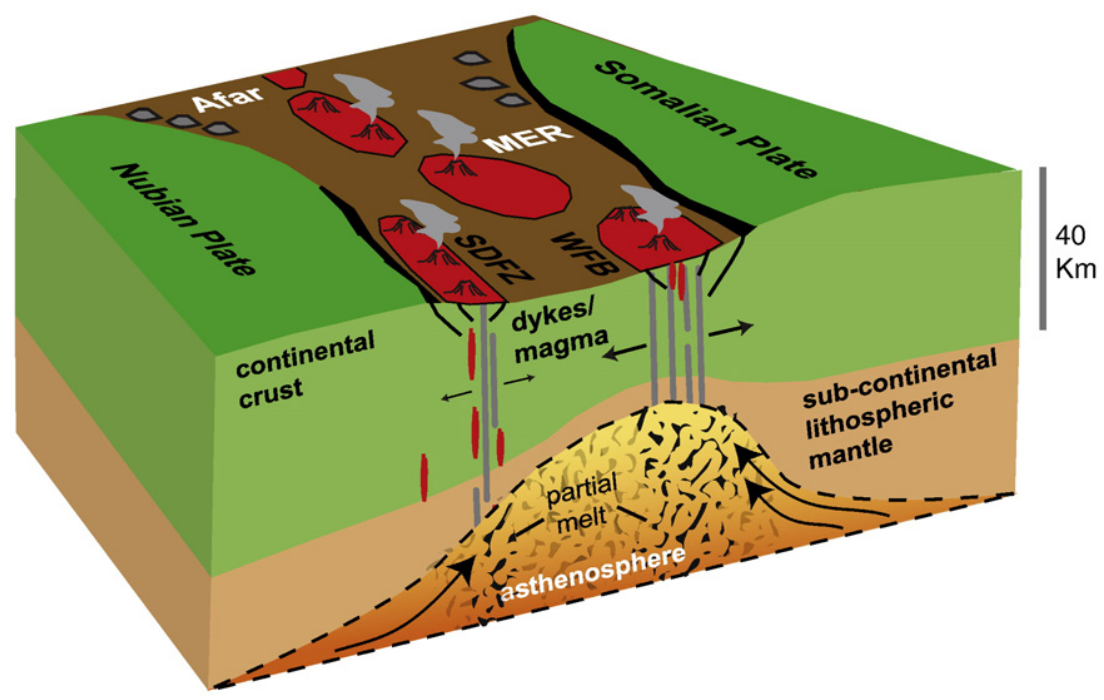

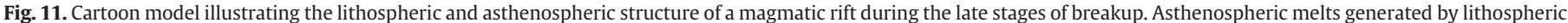

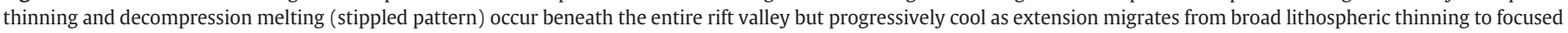

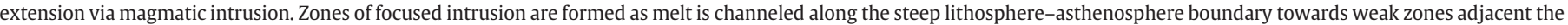
rift border faults forming linear magmatic chains.

complicating influence of the Boru-Toru Structural High, magmas erupted in the SDFZ exhibit trace element patterns that are consistent with derivation from deeper sources when compared to the WFB (Fig. 11). This heterogeneity has been interpreted as a greater degree of lithospheric thinning accommodated by the WFB (Rooney, 2010), in agreement with geodetic estimates that indicate the majority of extension occurs within the WFB (80\%: Bilham et al., 1999) by magma intrusion (Ebinger and Casey, 2001). Asymmetric extension in a rift is not an unusual observation: previous studies have shown rift border faulting may be dominant along one margin (Hayward and Ebinger, 1996). However, continued asymmetric extension during the transition to intrusion dominated strain may also have implications for the subsequent development of proto-oceanic spreading centres.

\subsection{Comparison of the MER with oceanic spreading segments}

Geochemical segmentation of oceanic spreading centres is a wellestablished observation which shows that lithospheric discontinuities between adjacent ridge segments correlate with geochemical heterogeneities in the basalts erupted within the segments (e.g. Langmuir et al., 1986; Macdonald et al., 1988; 1991; Sinton et al., 1991; White et al., 2001; Sinton et al., 2003; Standish et al., 2008). Heterogeneities in the mantle source of oceanic ridge basalts correlate with first-order segmentation - i.e. a physical off-sets of the ridge axis (e.g. Langmuir et al., 1986; Sinton et al., 1991; Standish et al., 2008). Lower order discontinuities typically reflect differences in the degree of melting or liquid line of descent (e.g. Macdonald et al., 1991; Sinton et al., 1991). Even at ultra-slow spreading centres, ridge segmentation defines the majority of geochemical variability in MORB (White et al., 2001; Standish et al., 2008). The geochemical characteristics of basalts erupted within the WFB and SDFZ exhibit substantial within-segment heterogeneity. Much of this variation relates to fractionation and assimilation within the continental crust, however differences in the melting column depth between adjacent cinder cones (Fig 9), and within-segment trace element and isotopic heterogeneity (Furman et al., 2006) implies melt extraction and eruption on much smaller length scales than that observed in oceanic spreading segments. The preservation of smallscale source provinciality along the WFB and SDFZ and the wide range of compositions erupted within individual segments are both inconsistent with observations at very-slow spreading ridges where melt is wellmixed on a segment scale (White et al., 2001).
Our geochemical observations are consistent with geophysical studies that have shown the velocity structure of the uppermost mantle beneath the MER shows no correlation with crustal magmatic segmentation (Bastow et al., 2005; Bastow et al., 2008). Thus, while the crustal structure of the MER is segmented and currently resembles an oceanic spreading centre (e.g. Ebinger and Casey, 2001; Keranen et al., 2004; Casey et al., 2006), the upper mantle and magmatic processes active in ocean basins are not yet operating beneath the MER.

\section{Summary}

Within the MER, extension is dominantly accommodated by intrusion in the WFB and to a lesser extent the SDFZ. Magmas erupted in these seismically and volcanically active zones of extension therefore record rifting processes since the onset of intrusionaccommodated extension. Existing studies have shown that the asymmetry in extension between the dominant WFB and subordinate SDFZ also correlates with geochemical evidence of across-rift shallowing of the melting column related to the preferential thinning of the lithosphere under the WFB. Enhanced extension within the WFB has also resulted in a more developed magmatic plumbing system compared to the SDFZ (Fig. 11). We have shown that the mantle melting columns from which MER basalts are extracted are also fundamentally influenced by lithospheric structures formed during earlier syn-rift stretching. These results highlight the central role of the rift's mechanical structure in controlling the development of mantle melting during this phase of rift evolution.

Studies of crustal structure in the MER have shown compelling similarities between the segmentation observed in the MER and oceanic ridges (Hayward and Ebinger 1996; Keranen et al., 2004; Casey et al., 2006). However, mantle structure has yet to organise into the punctuated upwellings expected at a fully formed oceanic ridge (Bastow et al., 2008). Magmas erupted in the WFB and SDFZ exhibit significant trace element and isotopic heterogeneity that has been interpreted in terms of variations in the inferred melting column depth (Rooney 2010; this study) and also mantle source regions (e.g. Furman et al., 2006). These variations may be observed within an individual segment, requiring melt extraction and eruption at much smaller length scales than is typical for slow-spreading oceanic ridges (e.g. White et al., 2001). When combined with seismic images of 
upper mantle structure, our results support an interpretation that the mantle structure and lithospheric magmatic plumbing system of the MER has not yet evolved to that observed in oceanic spreading ridges.

\section{Acknowledgements}

We thank the members of the EAGLE team for many fruitful discussions. We acknowledge the constructive reviews of Francesco Mazzarini and an anonymous reviewer that significantly improved this contribution.

\section{References}

Abebe, T., Mazzarini, F., Innocenti, F., Manetti, P., 1998. The Yerer-Tullu Wellel volcanotectonic lineament; a transtensional structure in central Ethiopia and the associated magmatic activity. Journal of African Earth Sciences 26 (1), 135-150.

Abebe, B., Acocella, V., Korme, T., Ayalew, D., 2007. Quaternary faulting and volcanism in the main Ethiopian Rift. Journal of African Earth Sciences 48 (2-3), 115-124.

Acocella, V., Korme, T., Salvini, F., 2003. Formation of normal faults along the axial zone of the Ethiopian Rift. Journal of Structural Geology 25 (4), 503-513.

Agostini, A., Corti, G., Zeoli, A., Mulugeta, G., 2009. Evolution, pattern, and partitioning of deformation during oblique continental rifting: inferences from lithospheric-scale centrifuge models. Geochemistry Geophysics Geosystems 10, Q11015. doi:10.1029/2009gc002676.

Ayalew, D., Gibson, S.A., 2009. Head-to-tail transition of the Afar mantle plume: geochemical evidence from a Miocene bimodal basalt-rhyolite succession in the Ethiopian Large Igneous Province. Lithos 112 (3-4), 461-476.

Ayalew, D., Marty, B., Barbey, P., Ketefo, E., 2006. Sub-lithospheric source for quaternary alkaline Tepi shield, southwest Ethiopia. Geochemical Journal 40 (1), 47-56

Ayele, A., Stuart, G., Bastow, I., Keir, D., 2007. The August 2002 earthquake sequence in north Afar: insights into the neotectonics of the Danakil microplate. Journal of African Earth Sciences 48 (2-3), 70-79.

Ayele, A., Keir, D., Ebinger, C., Wright, T.J., Stuart, G.W., Buck, W.R., Jacques, E., Ogubazghi, G., Sholan, J., 2009. September 2005 mega-dike emplacement in the Manda-Harraro nascent oceanic rift (Afar depression). Geophysical Research Letters 36, L20306. doi:10.1029/2009gl039605.

Bastow, I.D., Stuart, G.W., Kendall, J.M., Ebinger, C.J., 2005. Upper-mantle seismic structure in a region of incipient continental breakup: northern Ethiopian rift. Geophysical Journal International 162 (2), 479-493.

Bastow, I.D., Nyblade, A.A., Stuart, G.W., Rooney, T.O., Benoit, M.H., 2008. Rifting at the edge of the African low velocity anomaly. Geochemistry Geophysics Geosystems Q12022. doi:10.1029/2008GC002107.

Bastow, I.D., Pilidou, S., Kendall, J.M., Stuart, G.W., 2010. Melt-induced seismic anisotropy and magma assisted rifting in Ethiopia: evidence from surface waves. Geosystems Q0AB05. doi:10.1029/2010GC003036.

Bastow, I.D., Keir, D. and Daly, E., 2010a. Project EAGLE: probing the transition from continental rifting to incipient sea floor spreading in Ethiopia. GSA Special Publication in press.

Behn, M.D., Buck, W.R., Sacks, I.S., 2006. Topographic controls on dike injection in volcanic rift zones. Earth and Planetary Science Letters 246 (3-4), 188-196.

Benoit, M.H., Nyblade, A.A., Pasyanos, M.E., 2006a. Crustal thinning between the Ethiopian and East African plateaus from modeling Rayleigh wave dispersion. Geophysical Research Letters 33 (13), L13301. doi:10.1029/2006gl025687.

Benoit, M.H., Nyblade, A.A., VanDecar, J.C., 2006b. Upper mantle P-wave speed variations beneath Ethiopia and the origin of the Afar hotspot. Geology 34 (5), 329-332.

Beutel, E., van Wijk, J., Ebinger, C., Keir, D., Agostini, A., 2010. Formation and stability of magmatic segments in the Main Ethiopian and Afar rifts. Earth and Planetary Science Letters 293 (3-4), 225-235.

Bialas, R.W., Buck, W.R., Qin, R., 2010. How much magma is required to rift a continent? Earth and Planetary Science Letters 292, 68-78.

Bilham, R., Bendick, R., Larson, K., Mohr, P., Braun, J., Tesfaye, S., Asfaw, L., 1999. Secular and tidal strain across the main Ethiopian rift. Geophysical Research Letters 26 (18), 2789-2792.

Boccaletti, M., Getaneh, A., Mazzuoli, R., Tortorici, L., Trua, T., 1995. Chemical variations in a bimodal magma system; the Plio-Quaternary volcanism in the Dera Nazret area (Main Ethiopian Rift, Ethiopia). Africa Geoscience Review 2 (1), 37-60.

Boccaletti, M., Mazzuoli, R., Bonini, M., Trua, T., Abebe, B., 1999a. Plio-Quaternary volcanotectonic activity in the northern sector of the Main Ethiopian Rift; relationships with oblique rifting. Journal of African Earth Sciences 29 (4), 679-698.

Boccaletti, M., Bonini, M., Mazzuoli, R., Trua, T., 1999b. Pliocene-Quaternary volcanism and faulting in the northern Main Ethiopian Rift (with two geological maps at scale 1:50,000). Giardini Editore Pisa Italy (ITA) Acta Vulcanologica 11 (1), 83-97.

Bonini, M., Souriot, T., Boccaletti, M., Brun, J.P., 1997. Successive orthogonal and oblique extension episodes in a rift zone: laboratory experiments with application to the Ethiopian Rift. Tectonics 16 (2), 347-362.

Bonini, M., Sokoutis, D., Mulugeta, G., Boccaletti, M., Corti, G., Innocenti, F., Manetti, P., Mazzarini, F., 2001. Dynamics of magma emplacement in centrifuge models of continental extension with implications for flank volcanism. Tectonics 20 (6), 1053-1065.

Bonini, M., Corti, G., Innocenti, F., Manetti, P., Mazzarini, F., Abebe, T., Pecskay, Z., 2005. Evolution of the Main Ethiopian Rift in the frame of Afar and Kenya rifts propagation TC1007 Tectonics (1). doi:10.1029/2004TC00168.
Bosworth, W., Crevello, P., Winn, R.D., Steinmetz, J., 1998. Structure, sedimentation, and basin dynamics during rifting of the Gulf of Suez and northwestern Red Sea. In: Purser, B.H., Bosence, D.W.J. (Eds.), Sedimentation and Tectonics of Rift Basins: Red Sea-Gulf of Aden. Chapman and Hall, London, pp. 77-96.

Bosworth, W., Huchon, P., McClay, K., 2005. The Red Sea and Gulf of Aden basins. Journal of African Earth Sciences 43 (1-3), 334-378.

Brotzu, P., Morbidelli, L., Piccirillo, E.M., Traversa, G., 1974. Petrological features of Boseti Mountains, a complex volcanic system in the axial portion of the main Ethiopian Rift. Bulletin Volcanologique 38, 206-234.

Brotzu, P., Ganzerli-Valentini, M.T., Morbidelli, L., Piccirillo, E.M., Stella, R., Traversa, G., Ewart, A., Gupta, M.L., 1981. Basaltic volcanism in the northern sector of the Main Ethiopian Rift. Journal of Volcanology and Geothermal Research 10, 365-382.

Brown, F.H., Fuller, C.R., 2008. Stratigraphy and tephra of the Kibish Formation, southwestern Ethiopia. Journal of Human Evolution 55 (3), 366-403.

Buck, W.R., 2004. Consequences of asthenospheric variability on continental rifting. In: Karner, G., Taylor, B., Driscoll, N.W., Kohlstedt, D.L. (Eds.), Rheology and Deformation of the Lithosphere at Continental Margins. Columbia University Press, New York, pp. 1-30.

Buck, W.R., 2006. The role of magma in the development of the Afro-Arabian rift system. In: Yirgu, G., Ebinger, C., Maguire, P. (Eds.), The Afar Volcanic Province within the East African Rift System. Special Publication of the Geological Society, London, pp. 43-54.

Buck, W.R., Einarsson, P., Brandsdottir, B., 2006. Tectonic stress and magma chamber size as controls on dike propagation: constraints from the 1975-1984 Krafla rifting episode B12404, Journal of Geophysical Research-Solid Earth 111 (B12). doi:10.1029/2005jb003879.

Calais, E., d'Oreye, N., Albaric, J., Deschamps, A., Delvaux, D., Deverchere, J., Ebinger, C., Ferdinand, R.W., Kervyn, F., Macheyeki, A.S., Oyen, A., Perrot, J., Saria, E., Smets, B., Stamps, D.S., Wauthier, C., 2008. Strain accommodation by slow slip and dyking in a youthful continental rift, East Africa. Nature 456 (7223), 783-787.

Camp, V.E., Roobol, M.J., 1989. The Arabian Continental Alkali Basalt Province. 1. Evolution of Harrat-Rahat, Rahat, Kingdom-of-Saudi-Arabia. Geological Society of America Bulletin 101 (1), 71-95.

Camp, V.E., Roobol, M.J., Hooper, P.R., 1991. The Arabian Continental Alkali Basalt Province. 2. Evolution of Harrats Khaybar, Ithnayn, and Kura, Kingdom of SaudiArabia. Geological Society of America Bulletin 103 (3), 363-391.

Camp, V.E., Roobol, M.J., Hooper, P.R., 1992. The Arabian Continental Alkali Basalt Province. 3. Evolution of Harrat Kishb, Kingdom of Saudi-Arabia. Geological Society of America Bulletin 104 (4), 379-396.

Casey, M., Ebinger, C., Keir, D., Gloaguen, R., Mohamed, F., 2006. Strain accomadation in transitional rifts: extension by magma intrusion and faulting in Ethiopian rift magmatic segments. In: Yirgu, G., Ebinger, C., Maguire, P. (Eds.), The Afar Volcanic Province within the East African Rift System. Special Publication of the Geological Society, London, pp. 143-164.

Chadwick, W.W., Dieterich, J.H., 1995. Mechanical modeling of circumferential and radial dike intrusion on Galapagos Volcanos. Journal of Volcanology and Geothermal Research 66 (1-4), 37-52.

Chernet, T., Hart, W.K., Aronson, J.L., Walter, R.C., 1998. New age constraints on the timing of volcanism and tectonism in the northern Main Ethiopian Rift-southern Afar transition zone (Ethiopia). Journal of Volcanology and Geothermal Research 80 (3-4), 267-280.

Chorowicz, J., Collet, B., Bonavia, F.F., Korme, T., 1994. Northwest to north-northwest extension direction in the Ethiopian Rift deduced from the orientation of extension structures and fault-slip analysis. Geological Society of America Bulletin 106 (12), 1560-1570.

Cole, J.W., 1969. Gariboldi Volcanic Complex, Ethiopia. Bulletin Volcanologique 33, 566-578.

Cole, J.W., 1990. Structural control and origin of volcanism in the Taupo Volcanic Zone, New-Zealand. Bulletin of Volcanology 52 (6), 445-459.

Cornwell, D.G., Mackenzie, G.D., England, R.W., Maguire, P.K.H., Asfaw, L.M., Oluma, B. 2006. Northern Main Ethiopian Rift crustal structure from new high-precision gravity data. In: Yirgu, G., Ebinger, C., Maguire, P. (Eds.), The Afar Volcanic Province within the East African Rift System. Special Publication of the Geological Society, London, pp. 307-322.

Cornwell, D.G., Maguire, P.K.H., England, R.W., Stuart, G.W., 2010. Imaging detailed crusta structure and magmatic intrusion across the Ethiopian Rift using a dense linear broadband array. Geochemistry Geophysics Geosystems 11, Q0AB03. doi:10.1029/ 2009GC002637.

Corti, G., 2008. Control of rift obliquity on the evolution and segmentation of the main Ethiopian rift. Nature Geoscience 1 (4), 258-262.

Corti, G., 2009. Continental rift evolution: from rift initiation to incipient break-up in the Main Ethiopian Rift, East Africa. Earth-Science Reviews 96 (1-2), 1-53.

Daly, E., Keir, D., Ebinger, C.J., Stuart, G.W., Bastow, I.D., Ayele, A., 2008. Crustal tomographic imaging of a transitional continental rift: the Ethiopian rift Geophysical Journal International 172 (3), 1033-1048.

Davidson, A., Rex, D.C., 1980. Age of Volcanism and Rifting in Southwestern Ethiopia Nature 283 (5748), 657-658.

Deniel, C., Vidal, P., Coulon, C., Vellutini, P.J., 1994. Temporal evolution of mantle sources during continental rifting - the volcanism of Djibouti (Afar). Journal of Geophysical Research-Solid Earth 99 (B2), 2853-2869.

Dickinson, D.R., Gibson, I.L., 1972. Feldspar fractionation and anomalous Sr-87/Sr-86 ratios in a suite of peralkaline silicic rocks. Geological Society of America Bulletin 83 (1), 231-240.

Dugda, M.T., Nyblade, A.A., Julia, J., Langston, C.A., Ammon, C.J., Simiyu, S., 2005. Crustal structure in Ethiopia and Kenya from receiver function analysis: implications for rift development in eastern Africa B01303 Journal of Geophysical Research-Solid Earth 110 (B1). doi:10.1029/2004JB003065. 
Dugda, M.T., Nyblade, A.A., Julia, J., 2007. Thin lithosphere beneath the Ethiopian plateau revealed by a joint inversion of Rayleigh wave group velocities and receiver functions B08305, Journal of Geophysical Research-Solid Earth 112 (B8). doi:10.1029/2006JB004918

Ebinger, C.J., Casey, M., 2001. Continental breakup in magmatic provinces: an Ethiopian example. Geology 29 (6), 527-530.

Ebinger, C.J., Hayward, N.J., 1996. Soft plates and hot spots: views from afar. Journal of Geophysical Research-Solid Earth 101 (B10), 21859-21876.

Ebinger, C.J., Yemane, T., WoldeGabriel, G., Aronson, J.L., Walter, R.C., 1993. Late EoceneRecent volcanism and faulting in the southern main Ethiopian Rift. Journal of the Geological Society of London 150 (1), 99-108.

Ebinger, C.J., Jackson, J.A., Foster, A.N., Hayward, N.J., 1999. Extensional basin geometry and the elastic lithosphere. Philosophical Transactions of the Royal Society of London Series a - Mathematical Physical and Engineering Sciences 357 (1753), 741-762.

Ebinger, C.J., Yemane, T., Harding, D.J., Tesfaye, S., Kelley, S., Rex, D.C., 2000. Rift deflection, migration, and propagation: linkage of the Ethiopian and Eastern rifts, Africa. Geological Society of America Bulletin 112 (2), 163-176.

Fantzotti, P.L., Sgavetti, M., 1998. Tectonic and sedimentary evolution of the eastern Gulf of Aden continental margins: new structural and stratigraphic data from Somalia and Yemen. In: Purser, B.H., Bosence, D.W.J. (Eds.), Sedimentation and Tectonics of Rift Basins: Red Sea-Gulf of Aden. Chapman and Hall, London, pp. 56-76.

Ferguson, D.J., Barnie, T.D., Pyle, D.M., Oppenheimer, C., Yirgu, G., Lewi, E., Kidane, T. Carn, S., Hamling, I.J., 2010. Recent rift-related volcanism in Afar, Ethiopia. Earth and Planetary Science Letters 292, 409-418.

Forte, A.M., Quere, S., Moucha, R., Simmons, N.A., Grand, S.P., Mitrovica, J.X., Rowley, D.B., 2010. Joint seismic-geodynamic-mineral physical modelling of African geodynamics: a reconciliation of deep-mantle convection with surface geophysical constraints. Earth and Planetary Science Letters 295, 329-341.

Furman, T., Bryce, J.G., Rooney, T., Hanan, B.B., Yirgu, G., Ayalew, D., 2006. Heads and tails: 30 million years of the Afar plume. In: Yirgu, G., Ebinger, C., Maguire, P. (Eds.), The Afar Volcanic Province within the East African Rift System. Special Publication of the Geological Society, London, pp. 95-120.

Gasparon, M., Innocenti, F., Manetti, P., Peccerillo, A., Tsegaye, A., 1993. Genesis of the Pliocene to Recent bimodal mafic-felsic volcanism in the Debre Zeyt area, central Ethiopia; volcanological and geochemical constraints. Journal of African Earth Sciences 17 (2), 145-165.

George, R., Rogers, N., 1999. The petrogenesis of Plio-Pleistocene alkaline volcanic rocks from the Tosa Sucha region, Arba Minch, southern Main Ethiopian Rift. Acta Vulcanologica 11 (1), 121-130.

George, R.M., Rogers, N.W., 2002. Plume dynamics beneath the African Plate inferred from the geochemistry of the Tertiary basalts of southern Ethiopia. Contributions to Mineralogy and Petrology 144 (3), 286-304.

George, R., Rogers, N., Kelley, S., 1998. Earliest magmatism in Ethiopia: evidence for two mantle plumes in one flood basalt province. Geology 26 (10), 923-926.

Gibson, I.L., 1975. A review of the geology, petrology and geochemistry of the volcano Fantale. Bulletin Volcanologique 38, 791-802.

Grand, S.P., 2002. Mantle shear-wave tomography and the fate of subducted slabs. Philosophical Transactions of the Royal Society of London Series a - Mathematical. Physical and Engineering Sciences 360 (1800), 2475-2491.

Hamling, I.J., Ayele, A., Bennati, L., Calais, E., Ebinger, C.J., Keir, D., Lewi, E., Wright, T.J., Yirgu, G., 2009. Geodetic observations of the ongoing Dabbahu rifting episode: new dyke intrusions in 2006 and 2007. Geophysical Journal International 178 (2), 989-1003.

Hanan, B.B., Graham, D.W., 1996. Lead and helium isotope evidence from oceanic basalts for a common deep source of mantle plumes. Science 272 (5264), 991-995.

Hart, S.R., 1984. A large-scale isotope anomaly in the southern-hemisphere mantle. Nature 309 (5971), 753-757.

Hart, W.K., Woldegabriel, G., Walter, R.C., Mertzman, S.A., 1989. Basaltic volcanism in Ethiopia - Constraints on continental rifting and mantle interactions. Journal of Geophysical Research-Solid Earth and Planets 94 (B6), 7731-7748.

Hayward, N.J., Ebinger, C.J., 1996. Variations in the along-axis segmentation of the Afar Rift system. Tectonics 15 (2), 244-257.

Hofmann, C., Courtillot, V., Feraud, G., Rouchett, P., Yirgu, G., Ketefo, E., Pik, R., 1997. Timing of the Ethiopian flood basalt event and implications for plume birth and global change. Nature 389 (6653), 838-841.

Hopper, J.R., Buck, W.R., 1993. The initiation of rifting at constant tectonic force - role of diffusion creep. Journal of Geophysical Research-Solid Earth 98 (B9), 16213-16221.

Hughes, G.W., Filatoff, J., 1995. New biostratigraphic constraints on Saudi Arabian Red Sea pre- and syn-rift sequences. In: Al-Husseini, M.I. (Ed.), Middle East Petroleum Geosciences, Geo94. Gulf Petrolink, Bahrain, pp. 517-528.

Huismans, R.S., Beaumont, C., 2003. Symmetric and asymmetric lithospheric extension: relative effects of frictional-plastic and viscous strain softening. Journal of Geophysical Research-Solid Earth 108 (B10), 2496. doi:10.1029/2002jb002026.

Kazmin, V., Berhe, S.M., Wondm-Agennehu, B., 1981. Geological Map of the Ethiopian Rift. The Ethiopian Government - Ministry of Mines. Energy and Water Resources, Addis Ababa.

Keir, D., Stuart, G.W., Jackson, A., Ayele, A., 2006a. Local earthquake magnitude scale and seismicity rate for the Ethiopian rift. Bulletin of the Seismological Society of America 96 (6), 2221-2230.

Keir, D., Ebinger, C.J., Stuart, G.W., Daly, E., Ayele, A., 2006b. Strain accommodation by magmatism and faulting as rifting proceeds to breakup: seismicity of the northern Ethiopian rift B05314, Journal of Geophysical Research-Solid Earth 111 (B5) doi:10.1029/2005jb003748.

Keir, D., Hamling, I.J., Ayele, A., Calais, E., Ebinger, C., Wright, T.J., Jacques, E., Mohamed, K., Hammond, J.O.S., Belachew, M., Baker, E., Rowland, J.V., Lewi, E., Bennati, L, 2009a. Evidence for focused magmatic accretion at segment centers from latera dike injections captured beneath the Red Sea rift in Afar. Geology 37 (1), 59-62.
Keir, D., Bastow, I., Whaler, K., Daly, E., Cornwell, D.G., Hautot, S., 2009b. Lower-crustal earthquakes near the Ethiopian rift induced by magma injection. Geochemistry Geophysics Geosystems Q0AB02. doi:10.1029/2009GC002382.

Kendall, J.-M., Stuart, G.W., Ebinger, C., Bastow, I.D., Keir, D., 2005. Magma-assisted rifting in Ethiopia. Nature 433 (7022), 146-148.

Kendall, J.M., Pilidou, S., Keir, D., Bastow, I., Stuart, G.W., Ayele, A., 2006. Mantle upwellings, melt migration and the rifting of Africa: insights from seismic anisotropy. In: Yirgu, G., Ebinger, C., Maguire, P. (Eds.), The Afar Volcanic Province within the East African Rift System. Geological Society of London Special Publication, London, pp. 55-72.

Keranen, K., Klemperer, S.L., 2008. Discontinuous and diachronous evolution of the Main Ethiopian Rift: implications for development of continental rifts. Earth and Planetary Science Letters 265 (1-2), 96-111.

Keranen, K., Klemper, S.L., Gloaguen, R., Grp, E.W., 2004. Three-dimensional seismic imaging of a protoridge axis in the Main Ethiopian rift. Geology 32 (11), 949-952.

Kieffer, B., Arndt, N., Lapierre, H., Bastien, F., Bosch, D., Pecher, A., Yirgu, G., Ayalew, D., Weis, D., Jerram, D.A., Keller, F., Meugniot, C., 2004. Flood and shield basalts from Ethiopia: magmas from the African superswell. Journal of Petrology 45 (4), 793-834.

Korme, T., Chorowicz, J., Collet, B., Bonavia, F.F., 1997. Volcanic vents rooted on extension fractures and their geodynamic implications in the Ethiopian Rift. Journal of Volcanology and Geothermal Research 79 (3-4), 205-222.

Korme, T., Acocella, V., Abebe, B., 2004. The role of pre-existing structures in the origin, propagation and architecture of faults in the main Ethiopian rift. Gondwana Research 7 (2), 467-479.

Kurz, T., Gloaguen, R., Ebinger, C., Casey, M., Abebe, B., 2007. Deformation distribution and type in the Main Ethiopian Rift (MER): a remote sensing study. Journal of African Earth Sciences 48 (2-3), 100-114.

Kusznir, N.J., Park, R.G., 1987. The extensional strength of the continental lithosphere: its dependence on geothermal gradient, and crustal composition and thickness. In: Coward, M.P. (Ed.), Continental Extensional Tectonics. Geological Society, London, Special Publications, London, pp. 35-52.

Lahitte, P., Gillot, P.-Y., Courtillot, V., 2003. Silicic central volcanoes as precursors to rift propagation; the Afar case. Earth and Planetary Science Letters 207 (1-4), 103-116. Langmuir, C.H., Bender, J.F., Batiza, R., 1986. Petrological and Tectonic Segmentation of the East Pacific Rise, 5-Degrees-30'-14-Degrees-30'-N. Nature 322 (6078), 422-429.

Levitte, D., Columba, J., Mohr, P., 1974. Reconnaissance Geology of Amaro Horst, Southern Ethiopian Rift. Geological Society of America Bulletin 85 (3), 417-422.

Li, C., van der Hilst, R.D., Engdahl, E.R., Burdick, S., 2008. A new global model for P wave speed variations in Earth's mantle. Geochemistry Geophysics Geosystems 9, Q05018. doi:10.1029/2007gc001806.

Macdonald, K.C., Fox, P.J., Perram, L.J., Eisen, M.F., Haymon, R.M., Miller, S.P., Carbotte, S. M., Cormier, M.H., Shor, A.N., 1988. A new view of the mid-ocean ridge from the behavior of ridge-axis discontinuities. Nature 335 (6187), 217-225.

Macdonald, K.C., Scheirer, D.S., Carbotte, S.M., 1991. Midocean ridges - discontinuities, segments and giant cracks. Science 253 (5023), 986-994.

Mackenzie, G., Thybo, H., Maguire, P., 2005. Crustal velocity structure across the Main Ethiopian Rift: results from 2-dimensional wide-angle seismic modelling. Geophysical Journal International 162, 994-1006.

Maguire, P., Keller, G.R., Klemper, S.L., Mackenzie, G., Keranen, K., Harder, S., O'Reilly, B., Thybo, H., Asfaw, L., Kahn, M., Amha, M., 2006. Crustal structure of the Northern Main Ethiopian Rift from the EAGLE controlled source survey; a snapshot of incipient lithospheric break-up. In: Yirgu, G., Ebinger, C., Maguire, P. (Eds.), The Afar Volcanic Province within the East African Rift System. Special Publication of the Geological Society, London, pp. 269-292.

Mazzarini, F., 2007. Vent distribution and crustal thickness in stretched continental crust: the case of the Afar Depression (Ethiopia). Geosphere 3 (3), 152-162.

Mazzarini, F., Corti, G., Manetti, P., Innocenti, F., 2004. Strain rate and bimodal volcanism in the continental rift: Debre Zeyt volcanic field, northern MER, Ethiopia. Journal of African Earth Sciences 39 (3-5), 415-420.

McKenzie, D.P., 1978. Some remarks on the development of sedimentary basins. Earth and Planetary Science Letters 40, 25-32.

Mickus, K., Tadesse, K., Keller, G.R., Oluma, B., 2007. Gravity analysis of the main Ethiopian rift. Journal of African Earth Sciences 48 (2-3), 59-69.

Mohr, P.A., 1961. The geology, structure, and origin of the Bishoftu explosion craters. Bulletin of the Geophysical Observatory 2 (2), 65-101.

Mohr, P.A., 1962. The Ethiopian rift system. Bulletin of the Geophysical Observatory 3 (1), 33-62.

Mohr, P.A., 1967a. Further notes on the explosion craters of Bishoftu (Debre Zeit). Bulletin of the Geophysical Observatory 10, 99-112.

Mohr, P.A., 1967b. Major volcano-tectonic lineament in the Ethiopian rift system. Nature 213 (5077), 664-665.

Mohr, P., 1987. Structural style of continental rifting in Ethiopia: reverse decollements. EOS Trans. AGU September 1, 721-730.

Montelli, R., Nolet, G., Dahlen, F.A., Masters, G., 2006. A catalogue of deep mantle plumes: new results from finite-frequency tomography. Geochemistry Geophysics Geosystems 7, Q11007. doi:10.1029/2006GC001248.

Moore, J.M., Davidson, A., 1978. Rift Structure in Southern Ethiopia. Tectonophysics 46 (1-2), 159-173.

Morton, W.H., Rex, D.C., Mitchell, J.G., Mohr, P., 1979. Riftward younging of volcanic units in the Addis Ababa region, Ethiopian Rift valley. Nature 280 (5720), 284-288.

Nairn, I.A., Cole, J.W., 1981. Basalt Dikes in the 1886 Tarawera Rift. New Zealand Journal of Geology and Geophysics 24 (5-6), 585-592.

Parsons, T., Thompson, G.A., 1991. The role of magma overpressure in suppressing earthquakes and topography - worldwide examples. Science 253 (5026), 1399-1402. 
Peccerillo, A., Barberio, M.R., Yirgu, G., Ayalew, D., Barbieri, M., Wu, T.W., 2003. Relationships between mafic and peralkaline silicic magmatism in continental rift settings: a petrological, geochemical and isotopic study of the Gedemsa volcano, central Ethiopian rift. Journal of Petrology 44 (11), 2003-2032.

Peccerillo, A., Donati, C., Santo, A.P., Orlando, A., Yirgu, G., Ayalew, D., 2007. Petrogenesis of silicic peralkaline rocks in the Ethiopian rift: geochemical evidence and volcanological implications. Journal of African Earth Sciences 48 (2-3), 161-173.

Perez-Gussinye, M., Metois, M., Fernandez, M., Verges, J., Fullea, J., Lowry, A.R., 2009. Effective elastic thickness of Africa and its relationship to other proxies for lithospheric structure and surface tectonics. Earth and Planetary Science Letters 287 (1-2), 152-167.

Pik, R., Deniel, C., Coulon, C., Yirgu, G., Marty, B., 1999. Isotopic and trace element signatures of Ethiopian flood basalts; evidence for plume-lithosphere interactions. Geochimica et Cosmochimica Acta 63 (15), 2263-2279.

Rampey, M.L., Oppenheimer, C., Pyle, D.G., Yirgu, G., 2010. Caldera-forming eruptions of the Quaternary Kone Volcanic Complex, Ethiopia. Journal of African Earth Sciences $58,51-66$

Ritsema, J., van Heijst, H., 2000. New seismic model of the upper mantle beneath Africa. Geology 28 (1), 63-66.

Ronga, F., Lustrino, M., Marzoli, A., Melluso, L., 2010. Petrogenesis of a basaltcomendite-pantellerite rock suite: the Boseti Volcanic Complex (Main Ethiopian Rift). Mineralogy and Petrology 98 (1-4), 227-243.

Rooney, T.O., 2010. Geochemical evidence of lithospheric thinning in the southern Main Ethiopian Rift. Lithos 117, 33-48. doi:10.1016/j.lithos.2010.02.002.

Rooney, T., Furman, T., Yirgu, G., Ayalew, D., 2005. Structure of the Ethiopian lithosphere: xenolith evidence in the Main Ethiopian Rift. Geochimica et Cosmochimica Acta 69 (15), 3889-3910.

Rooney, T., Furman, T., Bastow, I.D., Ayalew, D., Gezahegn, Y., 2007. Lithospheric modification during crustal extension in the Main Ethiopian Rift. Journal of Geophysical Research, B, Solid Earth and Planets 112, B10201. doi:10.1029/ 2006JB004916.

Rowland, J.V., Baker, E., Ebinger, C.J., Keir, D., Kidane, T., Biggs, J., Hayward, N., Wright, T.J., 2007. Fault growth at a nascent slow-spreading ridge: 2005 Dabbahu rifting episode, Afar. Geophysical Journal International 171 (3), 1226-1246.

Royer, J.Y., Gordon, R.G., Horner-Johnson, B.C., 2006. Motion of nubia relative to Antarctica since $11 \mathrm{Ma}$ : implications for Nubia-Somalia, Pacific-North America, and India-Eurasia motion. Geology 34 (6), 501-504.

Rubin, A.M., 1990. A comparison of rift-zone tectonics in Iceland and Hawaii. Bulletin of Volcanology 52 (4), 302-319.

Rubin, A.M., Pollard, D.D., 1988. Dike-induced faulting in rift zones of Iceland and Afar. Geology 16 (5), 413-417.

Sicilia, D., Montagner, J.P., Cara, M., Stutzmann, E., Debayle, E., Lepine, J.C., Leveque, J.J., Beucler, E., Sebai, A., Roult, G., Ayele, A., Sholan, J.M., 2008. Upper mantle structure of shear-waves velocities and stratification of anisotropy in the Afar Hotspot region. Tectonophysics 462 (1-4), 164-177.

Simmons, N.A., Forte, A.M., Grand, S.P., 2007. Thermochemical structure and dynamics of the African superplume. Geophysical Research Letters 34 (2), L02301. doi:10.1029/2006GL028009.

Sinton, J.M., Smaglik, S.M., Mahoney, J.J., Macdonald, K.C., 1991. Magmatic processes at superfast spreading midocean ridges - glass compositional variations along the East Pacific Rise 13-degrees-23-degrees-S. Journal of Geophysical Research-Solid Earth and Planets 96 (B4), 6133-6155.

Sinton, J., Detrick, R., Canales, J.P., Ito, G., Behn, M., 2003. Morphology and segmentation of the western Galapagos Spreading Center, 90.5 degrees-98 degrees W: plumeridge interaction at an intermediate spreading ridge. Geochemistry Geophysics Geosystems 4, 8515. doi:10.1029/2003gc000609.

Sjogren, T., 1951. The Crater Lakes of Bishoftu present interesting geological argument. The Ethiopian Herald, Addis Ababa. pp. 5 articles.

Standish, J.J., Dick, H.J.B., Michael, P.J., Melson, W.G., O'Hearn, T., 2008. MORB generation beneath the ultraslow spreading Southwest Indian Ridge (9-25 degrees E): major element chemistry and the importance of process versus source. Geochemistry Geophysics Geosystems 9, Q05004. doi:10.1029/2008gc001959.

Stuart, G.W., Bastow, I., Ebinger, C., 2006. Crustal structure of the northern Main Ethiopian Rift from reciever function studies. In: Yirgu, G., Ebinger, C., Maguire, P. (Eds.), The Afar Volcanic Province within the East African Rift System. Geological Society of London Special Publications, London, pp. 253-267.

Sun, S.s., McDonough, W.F., 1989. Chemical and isotopic systematics of oceanic basalts: implications for mantle composition and processes. In: Saunders, In: A.D. (Ed.), Magmatism in the Ocean Basins. Geological Society, London, pp. 313-345.

Tadesse, S., Milesi, J.P., Deschamps, Y., 2003. Geology and mineral potential of Ethiopia: a note on geology and mineral map of Ethiopia. Journal of African Earth Sciences 36 (4), 273-313.
Tesfaye, S., Harding, D.J., Kusky, T.M., 2003. Early continental breakup boundary and migration of the Afar triple junction, Ethiopia. Geological Society of America Bulletin 115 (9), 1053-1067.

Tessema, A., Antoine, L.A.G., 2003. Variation in effective elastic plate thickness of the East Africa lithosphere. Journal of Geophysical Research-Solid Earth 108 (B5), 2224. doi:10.1029/2002jb002200.

Thybo, H., Nielsen, C.A., 2009. Magma-compensated crustal thinning in continental rift zones. Nature 457 (7231), 873-876.

Tiberi, C., Ebinger, C., Ballu, V., Stuart, G., Oluma, B., 2005. Inverse models of gravity data from the Red Sea-Aden-East African rifts triple junction zone. Geophysical Journal International 163 (2), 775-787.

Trua, T., Deniel, C., Mazzuoli, R., 1999. Crustal control in the genesis of Plio-Quaternary bimodal magmatism of the Main Ethiopian Rift (MER); geochemical and isotopic (Sr, Nd, Pb) evidence. Chemical Geology 155 (3-4), 201-231.

Ukstins, I.A., Renne, P.R., Wolfenden, E., Baker, J., Ayalew, D., Menzies, M., 2002 Matching conjugate volcanic rifted margins; (super 40) Ar/ (super 39) Ar chronostratigraphy of pre- and syn-rift bimodal flood volcanism in Ethiopia and Yemen. Earth and Planetary Science Letters 198 (3-4), 289-306.

van Wijk, J.W., Blackman, D.K., 2007. Development of en echelon magmatic segments along oblique spreading ridges. Geology 35 (7), 599-602.

Wang, K., Plank, T., Walker, J.D., Smith, E.I., 2002. A mantle melting profile across the basin and range, SW USA. Journal of Geophysical Research-Solid Earth 107 (B1), 2017. doi:10.1029/2001JB0002092.

Wang, Y., Forsyth, D.W., Savage, B., 2009. Convective upwelling in the mantle beneath the Gulf of California. Nature 462 (7272), 499-502.

Weaver, S.D., Sceal, J.S.C., Gibson, I.L., 1972. Trace-element data relevant to origin of trachytic and pantelleritic lavas in East African rift system. Contributions to Mineralogy and Petrology 36 (3), 181-194.

Webster, J.D., Taylor, R.P., Bean, C., 1993. Pre-eruptive melt composition and constraints on degassing of a water-rich pantellerite magma, Fantale Volcano, Ethiopia. Contributions to Mineralogy and Petrology 114 (1), 53-62.

Whaler, K., Hautot, S., 2006. Magnetotelluric studies of the northern Ethiopian rift. In: Yirgu, G., Ebinger, C., Maguire, P. (Eds.), The Afar Volcanic Province within the East African Rift System. Special Publication of the Geological Society, London, pp. 293-306.

White, R.S., Minshull, T.A., Bickle, M.J., Robinson, C.J., 2001. Melt generation at very slow-spreading oceanic ridges: constraints from geochemical and geophysical data. Journal of Petrology 42 (6), 1171-1196.

White, R.S., Smith, L.K., Roberts, A.W., Christie, P.A.F., Kusznir, N.J., Team, i, 2008. Lowercrustal intrusion on the North Atlantic continental margin. Nature 452 (7186), 460-464

Williams, F.M., Williams, M.A.J., Aumento, F., 2004. Tensional fissures and crustal extension rates in the northern part of the Main Ethiopian Rift. Journal of African Earth Sciences 38 (2), 183-197.

Woldegabriel, G., Aronson, J.L., 1987. Chow Bahir Rift - a failed rift in Southern Ethiopia. Geology 15 (5), 430-433.

WoldeGabriel, G., Aronson, J.L., Walter, R.C., 1990. Geology, geochronology, and rift basin development in the central sector of the Main Ethiopia Rift. Geological Society of America Bulletin 102 (4), 439-458.

Woldegabriel, G., Yemane, T., Suwa, G., White, T., Asfaw, B., 1991. Age of volcanism and rifting in the Burji-Soyoma area, Amaro Horst, southern Main Ethiopian Rift - geochronological and biochronologic data. Journal of African Earth Sciences 13 (3-4), 437-447.

WoldeGabriel, G., Hart, W.K., Katoh, S., Beyene, Y., Suwa, G., 2005. Correlation of PlioPleistocene Tephra in Ethiopian and Kenyan rift basins: temporal calibration of geological features and hominid fossil records. Journal of Volcanology and Geothermal Research 147 (1-2), 81-108.

Wolfenden, E., Ebinger, C., Yirgu, G., Deino, A., Ayalew, D., 2004. Evolution of the northern Main Ethiopian rift: birth of a triple junction. Earth and Planetary Science Letters 224 (1-2), 213-228.

Wolfenden, E., Ebinger, C., Yirgu, G., Renne, P.R., Kelley, S.P., 2005. Evolution of a volcanic rifted margin: southern Red Sea, Ethiopia. Geological Society of America Bulletin 117 (7-8), 846-864.

Wright, T.J., Ebinger, C., Biggs, J., Ayele, A., Yirgu, G., Keir, D., Stork, A., 2006. Magmamaintained rift segmentation at continental rupture in the 2005 Afar dyking episode. Nature 442, 291-294.

Yemane, T., WoldeGabriel, G., Tesfaye, S., Berhe, S.M., Durary, S., Ebinger, C., Kelley, S., 1999. Temporal and geochemical characteristics of Tertiary volcanic rocks and tectonic history in the southern Main Ethiopian Rift and the adjacent volcanic fields. Acta Vulcanologica 11 (1), 99-119.

Zanettin, B., 1978. The Evolution of the Chencha Escarpment and the Ganjuli Graben Neues Jahrbuch fur Geologie und Palaontologie. Monatshefte 8, 473-490. 